\title{
Ten years of Energy Efficiency: A bibliometric analysis
}

\author{
Andrea Trianni ${ }^{1, *}$, José M. Merigó ${ }^{1,2}$, Paolo Bertoldi ${ }^{3}$ \\ ${ }^{1}$ School of Information, Systems and Modelling, Faculty of Engineering and Information \\ Technology, University of Technology Sydney, 81 Broadway, Ultimo 2007, NSW, Australia \\ ${ }^{2}$ Department of Management Control and Information Systems, School of Economics and \\ Business, University of Chile, Av. Diagonal Paraguay 257, 8330015 Santiago, Chile \\ ${ }^{3}$ Directorate for Energy, Transport and Climate, European Commission Directorate \\ General Joint Research Centre, Ispra, Italy \\ Emails: Andrea.Trianni@uts.edu.au;Jose.Merigo@uts.edu.au; \\ paolo.bertoldi@ec.europa.eu \\ * corresponding author
}

Conflict of interest: the authors declare that they have no conflict of interest 


\title{
Ten years of Energy Efficiency: A bibliometric analysis
}

\begin{abstract}
Energy Efficiency is an international journal dedicated to research topics connected to energy with a focus on end-use efficiency issues. In 2018, the journal celebrates its $10^{\text {th }}$ anniversary. In order to mark it and analyse not only how the journal has been performing over the years, but also which are the trends for academic debate and research in this journal, this article presents a bibliometric overview of the publication and citation structure of the journal during period 2008-2017. The study relies on the Web of Science Core Collection and the Scopus database to collect the bibliographic results. Additionally, the work exploits the visualization of similarities (VOS) viewer software to map graphically the bibliographic material. The research analyses the most cited papers and the most popular keywords. Moreover, the paper studies how the journal connects with other international journals and identifies the most productive authors, institutions and countries. The results indicate that the journal has rapidly grown over the years, obtained a merited position in the scientific community, with contributions from authors all over the world (with Europe as most productive region). Moreover, the journal has focused so far mainly on energy efficiency issues in close relationship with policies and incentives, corporate energy efficiency, consumer behaviour and demand-side management programs, with both industrial, building and transport sectors widely involved. Our discussion concludes with suggested future research avenues, in particular towards coordinated efforts from different disciplines (technical, economic and socio-psychological ones) to address the emerging energy efficiency challenges.
\end{abstract}

Keywords: Energy Efficiency; bibliometric analysis; co-citation; VOS viewer.

\section{Introduction}

End-use energy efficiency is a major area of energy and climate policy and research. Under "end-use energy efficiency" are included both measures improving the efficiency of the energy services provided (i.e. the provision of the same service with less energy input) as well as measures for the energy conservation, irrespective of the technology adopted (i.e. 
switching off a lamp, lowering the thermostat, etc.) (Bertoldi et al, 2013). Energy efficiency started to attract the attention of policy makers and researchers in the seventies, at the time of the first oil embargo by OPEC in 1973, following the Yom Kipur War, when there was a sudden increase in the oil prices, and again in 1979 after the first oil crisis (Grossman, 2015; Rüdiger, 2019), which led to relevant concerns also in terms of energy security of supply. One key measure at the time to reduce oil import was the improvement of road vehicles efficiency (Geller et al., 1995). Following the first IPCC Assessment Report in 1990 and the establishment of the UNFCC in 1992, there was shared scientific evidence on the causes of climate change and on the need to mitigate the impact of climate change through the reduction of $\mathrm{CO}_{2}$ emissions due to fossil fuel combustion (Bertoldi, 2018). Energy efficiency was highlighted by researchers and policy makers as one of the key mitigation opportunities (Bertoldi, 2018). This triggered new and additional scientific research in energy efficiency and associated policies.

One of the key research topics was the "energy efficiency gap" (Jaffe and Stavins, 1994). Energy efficiency investments are often cost-effective in the sense that the capital invested is paid back within a few years. However, the investments in energy efficiency are not happening as expected due to a number of well investigated barriers (Hirst and Brown, 1990). Researchers focused on the "barriers" to energy efficiency investments and on the possible policies and measures to eliminate or reduce these barriers (Sorrell et al., 2004; Cagno et al., 2013).

Additional key topics of energy efficiency research related to barriers and policies that have emerged over the last 20 years are: the rebound effect (Nassen and Holmberg, 2009; Ruzzenenti and Bertoldi, 2017; Barker et al, 2009); the evaluation of energy efficiency policies (Brown et al., 2013; Vine, 2008; Cooper, 2018); the understanding of the consumers and organisations behaviour in relation to energy use and efficiency (e.g., Thollander et al., 2007; Cooremans, 2011; Cooremans, 2012).

The energy efficiency policy landscape in the past 50 years has evolved from individual policies to comprehensive national energy efficiency strategies remaining a key component of national energy and climate policies (Bertoldi, 2019). Recently, the European Commission announced the concept of "Energy Efficiency First" in its 2030 strategy, i.e. energy efficiency should be first considered in any decision related to energy use (EC, 2018). 
Notwithstanding the importance of energy efficiency in energy and climate research, the discussion over energy efficiency challenges did not have a dedicated journal where researchers from different disciplines (e.g. technologies and engineers, economists, psychologists, sociologists, political science researchers) could present their findings (very often of multidisciplinary nature). Some journals, such as Energy Policy, cover energy policies issues in all energy areas, from energy sources and production to distribution and energy markets, finally also covering end-use energy efficiency. Some other journals are rather devoted to specific end-use sectors such as buildings (Energy in Buildings) or industry (Journal of Cleaner Production).

Energy Efficiency was launched in 2008 as a research journal focused only on enduse energy efficiency and energy conservation. Energy Efficiency is a multidisciplinary journal linking different disciplines from engineers and economics to social and political science and to psychology. The major focus of Energy Efficiency has been on energy efficiency, conservation and demand reductions policies, with particular attention to economics and consumer behaviour studies (Bertoldi, 2008; Bertoldi 2018). Over the 10 years of Energy Efficiency, some of most prominent researchers in the field have published at least one article within the journal. Given that in 2018 the journal celebrates its $10^{\text {th }}$ anniversary, it is interesting to analyse not only how the journal has been performing over the years, but also which are the trends for academic debate and research in this journal. To do so, in this study we present a bibliometric overview of the publication and citation structure of the journal during period 2008-2017.

The remainder of the paper is organized as follows. In Section 2 we review the bibliometric methods of the work, devoting Section 3 to the presentation of our findings, according to the Web of Science Core Collection and Scopus collection databases. Section 4 develops a graphical mapping of the bibliographic material by means of the VOS viewer software, whilst in Section 5 we conclude the paper summarizing the main findings and sketching future research avenues.

\section{Methods}

This work relies on the Web of Science (WoS) Core Collection database to collect the bibliographic information (Merigó et al. 2015). This study searches the Energy Efficiency 
journal in WoS database selection the option of "publication name". At August 20 $0^{\text {th }} 2018$, the search finds 600 documents published in the journal. If we exclude 2018, 528 documents can be found. We have excluded 2018 as the analysis focuses on the first ten full years (20082017). In order to focus on scientific contributions, the present work limits considerations exclusively to manuscripts classified as "articles" and "reviews". As a consequence, the number of articles available for the analysis decreases to 514 documents.

In order to analyse the bibliographic material of documents published in Energy Efficiency, the paper adopts a bibliometric methodology (Merigó and Yang, 2017). The development of a bibliometric analysis of a journal is an approach becoming very popular in the literature. The main reason relies in the celebration of a special event like an anniversary, where journals are usually open to develop some retrospective evaluation and the use of a bibliometric methodology is a particularly suitable technique. Cobo et al. (2015) studies the first twenty-five years of Knowledge-Based Systems. Zou et al. (2017) studies the first twenty-three years of documents published in the Journal of Cleaner Production. Ji et al. (2018) analyses the first thirty years of Resources Conservation and Recycling and Cancino et al. (2017) the first 40 years of Computers \& Industrial Engineering. Laengle et al. (2017) presents a bibliometric overview of the first 40 years of the European Journal of Operational Research and Martinez-Lopez et al. (2018) of the European Journal of Marketing. Merigó et al. (2018) and Yu et al. (2018a) develop a bibliometric analysis of the first fifty years of Information Sciences. Yu et al. (2018b) analyse the IEEE Transactions on Fuzzy Systems and Yu et al (2018c) the Applied Intelligence journal. Therefore, a bibliometric analysis of the Energy Efficiency journal publications showcases the most relevant thematic areas covered in these first ten years of the journal, as well as how it connects with other international peer-reviewed journals and identifies the most productive authors, institutions and countries.

In order to measure and analyse the information (Ding et al. 2014), the work exploits several bibliometric indicators (Tur-Porcar et al. 2018) including the total number of publications and citations, the $h$-index (Alonso et al. 2009; Hirsch, 2005), the cites per paper and citation thresholds (Merigó et al. 2017). The choice for multiple indicators is, on the one hand, due to a lack of consensus on the optimal indicator for measuring academic research; on the other hand, as multiple indicators may offer a more comprehensive and multifaceted 
measurement of the journal performance. Still, so far, the most popular indicators are represented by the number of papers and citations. The first measures the journal productivity, while the latter rather looks at the influence and popularity of a given manuscript (Podsakoff et al. 2008). However, the importance for each of them in the analysis is yet unclear, since sometimes a decision maker could give more importance to productivity than on number of citations (Merigó et al. 2015), influencing editorial decisions. Therefore, by looking at multiple indicators, a reader may get a better picture of the results in order to draw more appropriate conclusions.

Another approach for results representation is through a graphical analysis that can graphically visualize how the leading elements of the journal (either authors, institutions, or keywords) connect between each other. In order to do so, the present work relies on the VOS viewer software (Van Eck and Waltman, 2010) and develops graphical maps by using cocitation (Small, 1973), bibliographic coupling (Kessler, 1963) and co-occurrence of author keywords (Wang et al. 2018). It is worth recalling some important elements: $i$ ) co-citation occurs when two documents receive a citation from the same third document; ii) bibliographic coupling appears when two documents cite the same third document; and iii) co-occurrence of author keywords measures those keywords appearing more frequently in the same documents.

\section{Results}

In the following, we report the findings from the bibliometric analyses, first by looking at the publication and citation structure of the Energy Efficiency journal, followed by an analysis of the influential documents in terms of citations and authorship.

\subsection{Publication and citation structure of Energy Efficiency}

Figure 1 shows the number of papers published by the journal over the last decade as well as the average number of manuscripts per volume. Energy Efficiency started publishing articles in 2008. As can be clearly inferred, the journal consistently grew over the years, almost quadruplicating from the very first 24 publications in 2008. Interestingly, the curve shaped its largest growth over the last five years, shifting from 45 publications in 2013 up to 93 in 2017. Moreover, at the very beginning, the journal was structured with four issues (from 2008 to 2013), then increasing to six issues per year. Therefore, it can be noted that the journal 
has significantly increased the number of manuscripts published per single issue, from about six per volume in 2008 to more than 15 in 2017. In this regard, we have further investigated with Energy Efficiency journal manager the reasons driving this increase. Interestingly, it emerged that the increase is neither due to a different marketing strategy nor dissemination activities, not either to a different approach to journal reviews. Rather, the remarkable growth is due to a natural diffusion of the information about the existence of the journal itself, with its aim and scope, that led to an increased number of submissions (as discussed further).

Additionally, always considering the period 2007-2017, when taking a closer look to the presence of special volumes, the journal has so far taken an approach predominantly focused on regular issues, with the vast majority of special volumes in the very beginning ( 7 out of the 8 special volumes have been published before 2014, 5 of which before 2010).

\section{$<$ Figure 1 >>}

Compared to other journals operating in the energy field, Energy Efficiency could be considered as a niche journal, very much focused on a relatively limited number of topics wide-ranging over "energy savings, energy consumption, energy sufficiency, and energy transition in all sectors" (as from the Energy Efficiency journal website). Nevertheless, the constant positive trend of the number of citations (as shown in Table 1), strongly confirmed also by analysing the set of manuscripts excluding self-citations (of all authors), shows that the journal has obtained a merited position in the scientific community.

$<<$ Table $1>>$

Nevertheless, the journal presents an excellent trend in terms of number of submissions, accepted manuscripts as well as downloads over the years (Figure 2). Firstly, the number of publications ranges from a minimum of 60 (2009) up to 590 (2017), with significant growth over the last five years. Additionally, the remarkable exponential growth in the number of downloads seems to indicate that, over the last decade, the journal has become an acknowledgeable place for the academic debate discussion over energy efficiency issues. Further, regarding accepted manuscripts, two main considerations can be drawn. First, 
we can note a notable increase, from 25 (in 2008) up to 95 (in 2017). Second, and more interestingly, by simultaneously looking at the submissions also, we can appreciate that the distance between them has significantly enlarged over the years. From earlier values of around $30 \%$ in the first 5 years, the journal has dramatically decreased the acceptance rate to around $15 \%$ over the last 5 years. This seems to indicate that the average quality of the articles has been increased over the years, in turn allowing the journal to pursue a strategy of premium quality, thus leading potential authors to perceive the journal as a high aspired to publish in.

\section{$<<$ Figure 2>>}

By clustering submissions by areas, we can see that the majority of the articles submitted deals with energy efficiency in specific technologies, e.g., internal combustion engines, residential appliances, motor systems, industry and buildings. In the buildings area many articles deal with technologies and techniques for buildings refurbishments, such as: insulation materials, façade design, natural ventilation, day-lighting and control systems. However, the strength of Energy Efficiency is in relation to analysis and research on energy efficiency policies, including evaluation, and other soft measures to remove barriers to energy efficiency. Key areas of research covered by the "more" successful published papers are: evaluation of energy savings including decomposition analysis and/or other econometric techniques; the provision of energy services and ESCOs; market-based instruments (ETS, white certificates, etc.); smart metering and feedback systems; consumer and organisation behaviour.

\subsection{Influential papers in Energy Efficiency}

When taking a further look in the set of most cited documents (as reported by Table 2), we can clearly identify some of the major discussion trends for the Energy Efficiency journal. Indeed, the discussion has covered energy efficiency issues for many sectors, manly residential (e.g., papers no. 1, 4, 6, 8, 9, 18) and industrial (e.g. papers no. 2, 3, 10, 13), with additional insights over other sectors (i.e. commercial, transport, and agriculture, respectively papers paper 7, 14, 20). Further, we can see that the discussion ranges from a broader set of levels: indeed, we can find either discussion of technologies and policy instruments for improved energy efficiency (e.g., paper no. 14, 15, 16), discussion of the behavior of final 
users (in terms of, e.g., barriers and driving forces, papers no 3, 10, 11, 19), as well as broader analyses (e.g., paper 5, 20), with additional insights over decision-making issues (e.g., paper 12 and 17).

More in detail, the most cited paper was published by Corinna Fisher and has 450 citations (Fischer, 2008). The manuscript presents a psychological model regarding feedback on electricity consumption illustrating how and why feedback works as a tool for customers to better control their consumption and ultimately save energy. The second most cited paper (134 citations) covers another key issue of the journal. It is authored by Ernst Worrell, Lenny Bernstein, Joyashree Roy, Lynn Price and Jochen Harnisch, who discuss the potential contribution to reduce energy use and GHG emissions in longer term by industrial energyefficiency technologies and policies (Worrell et al., 2009). The third most cited paper is coauthored by Patrik Thollander and Mikael Ottosson (118 citations), who have explored barriers and driving forces for improved energy efficiency by conducting an investigation in a Swedish pulp and paper industry (Thollander and Ottosson, 2008).

$<<$ Table 2>>

Similar considerations can be drawn by looking at the top most cited documents in Energy Efficiency publications. As depicted in Table 3, many top 30 most cited articles dispute barriers and drivers for energy efficiency at various levels (e.g., paper 1, 6-11), confirming that the discussion on "which" are the major issues to promote energy efficiency in different contexts, as well as the "how" to overcome them is quite vivid. For this reason, 7 out of the first 20 most cited manuscripts come from Energy Policy journal, as well as manuscripts from other journals discussing similar issues. Interestingly, only 3 out of the first 20 most cited documents are published in Energy Efficiency journal, showing not only that the journal itself is still in the phase of finding its own room, but also that the manuscripts published in the journal take the benefit of tackling the energy efficiency issue with a multifaceted approach. This, in turn, seems to call for further coordinated efforts from different disciplines (technical, economic and socio-psychological ones) to address the energy efficiency issue. 
$<<$ Table 3>>

\subsection{Leading authors, institutions and countries}

A broad set of authors (1,317 authors) has contributed with manuscripts to Energy Efficiency in this first decade, and Table 4 presents the most productive ones in the journal, by including several bibliometric indicators for Energy Efficiency publications - such as number of manuscripts, total number of citations, h-index, average number of cites per paper, as well as number of papers with more than 50 and 10 citations, respectively - so to draw a more general picture of the results for each author. Further, it is worth pointing out that only the last author affiliation has been listed. Ernst Worrell, one of the Energy Efficiency Associate Editors, is the most productive author of the journal, with 10 manuscripts. By taking a further look at most productive and influential institutions and countries, as shown by Table 5, we can find a major role by scholars with affiliations in the United States, the Netherlands, Germany, Sweden and Italy, thanks in part to the work of Ernst Worrell and his colleagues. Moreover, this analysis shows that the journal has so far received most of published contributions by European-based scholars (with the exception of the University of California Berkeley).

Next, by scaling up at country level (Table 6), we can see that the United States are the most productive country, followed by UK, Germany, Sweden and the Netherlands. Nevertheless, by looking at the number of publications per capita (as number of inhabitants), results are in favor of European countries. In particular, it is worth nothing that highest numbers can be observed for Germany and the Netherlands. Still, while European developed countries are the major contributors, we can interestingly note that non-European developing ones are emerging, in particular China, India and Brazil.

$<<$ Table 4>>

$<\langle$ Table 5>>

$<<$ Table 6>> 
Further, let us look into the citing articles of Energy Efficiency. The objective here is to identify those actors having cited Energy Efficiency the highest number of times. Note that the counting procedure only measures the number of articles independently of the number of citations given to Energy Efficiency in each article. Table 7 present the Top 30 citing actors in terms of universities, countries and authors.

\section{$<<$ Table 7>>}

Similar to what found above for the number of publications, the University of California Berkeley (Unites States of America) is the university citing more frequently Energy Efficiency, followed by Linköping University (Sweden) and Utrecht University (The Netherlands). Most of the leading institutions are from Europe, although there are also some North American and Asian universities in the list. Interestingly, most of the authors belonging to those universities are focused on energy efficiency issues applied to an industrial context. When generalizing at the country level, the results are consistent with the university level where the USA and China appear well placed in the ranking but, according to their size, their results are less remarkable than those from European countries being the main leaders in Energy Efficiency. Particularly, the results of the UK, Germany, Sweden, Netherlands and Italy are notable.

Another interesting issue for the analysis of the citing articles is to identify the journals citing in more papers the manuscripts published in Energy Efficiency. Figure 3 presents the Top 25 journals and classify the results from an annual perspective. Given that 2008 is the inaugural year of Energy Efficiency, the journal did not obtain any citation for that year. For this reason, the analysis of the annual performance begins in 2009.

$<<$ Figure 3>>

As previously noted, Energy Policy and the self-citations of Energy Efficiency emerge as most recurrent in the journal. Concerning Energy Policy, it presents a remarkable wave in the 2012-2015. This could be partially explained by the discussion about the European energy efficiency directive published in 2012, thus with plenty of energy policy 
manuscripts referring to discussion about how to successfully implement such directive. Regarding self-citations of the Energy efficiency journal, if on the one hand they increased over the years, one the other hand they are overall comparable to other journals. Moreover, Energy and Buildings, Journal of Cleaner Production, Applied Energy and Renewable \& Sustainable Energy Reviews also cite significantly the journal. This result seems pretty aligned with previous considerations on the topics covered by the journal and research approaches, showing the interconnections of energy efficiency issues with not only energyrelated journals, but also with more sustainability and industrial oriented ones, and, in conclusion, confirming that the journal is finding its space in the academic debate over energy efficiency.

\section{Mapping Energy Efficiency with VOS viewer software}

In order to deepen into the results of the previous section, we have developed a graphical mapping of the bibliographical material, by relying on the VOS viewer software (Van Eck and Waltman, 2010), one of the tools available for the development of a graphical analysis of the bibliographic material (Cobo et al. 2011). VOS viewer collects the bibliographic material producing graphical visualizations by using co-citation (Small, 1973), bibliographic coupling (Kessler, 1963) and co-occurrence of author keywords (Laengle et al. 2018).

First, we have looked into co-citation of journals, trying to identify the most cited journals in Energy Efficiency and connect those journals that more frequently receive citations from the same documents. Figure 4 presents the results considering a minimum citation threshold of ten cites and the one hundred strongest co-citation links.

\section{$<<$ Figure 4>>}

Here it is worth mentioning the tighter relationship with Energy Policy journal, being the most cited journal in Energy Efficiency, followed by Energy and Buildings, Energy Efficiency itself and Energy. These journals, together with Energy Economics, Applied Energy and Energy Conversion and Management, form the main core of the journal. This result clearly visualizes the focus of Energy Efficiency around topics connected to energy 
efficiency. Despite this primary focus, the journal also cited journals in other related areas including psychology, economics, management and engineering, showing the interest towards a multidisciplinary approach.

To see how the results are evolving through time, we have divided the data in two periods, namely 2008-2012 and 2013-2017. The reason for doing so is twofold: we show both the journals more frequently cited in the first years of the journal and how these results are evolving during the last years. Table 8 presents the thirty most cited journals in each period and the global results for the whole ten years of the journal.

\section{$<<$ Table $8>>$}

Energy Policy is by far the most cited journal in Energy Efficiency. However, the results show that Energy Economics and Energy were the second and third most cited journals in the first five years of the journal, but during the last five years, they have lost this position in the benefit of Energy and Buildings and Energy Efficiency. Although Energy Economics is now the fifth most cited journal in Energy Efficiency, it is worth noting that many other journals in economics are becoming highly cited in Energy Efficiency, including Ecological Economics, American Economic Review and the Review of Economics and Statistics.

Next, we have looked into the co-citations of authors highly cited in Energy Efficiency. Figure 5 presents the results considering a threshold of ten citations and visualizing the one hundred most representative connections.

\section{$<<$ Figure 5 $>>$}

Steve Sorrell, from the University of Sussex (UK), is the most cited author in Energy Efficiency followed by Beng Wah Ang, from the National University of Singapore. Interestingly, Steve Sorrell does not fall under the list of top leading authors (as shown in Table 4). Nevertheless, his work over barriers to (and more generally economics for) energy efficiency) represents a key topic that many Energy Efficiency authors recall in their studies. Note that some of these authors have a more interdisciplinary profile as Steve Sorrell, who 
also connects with other areas like, e.g. economics or political science. In this context, the aim of Figure 4 is to visualize the most cited authors in the journal independently of their specific profile that can be specialized in topics connected to energy efficiency or more general connecting with other fields. It is also worth noting that documents published by the International Energy Agency (IEA) and the European Commission are also highly cited in the journal.

Another interesting issue is to analyse the publications of universities in Energy Efficiency. For doing so, the article uses bibliographic coupling of universities (Valenzuela et al. 2017), which considers the institutions that publishes the highest number of documents in Energy Efficiency and connects those that cite same documents more frequently. Figure 6 visualizes the results (with a minimum threshold to appear in the graph of two documents) and shows the 100 most representative bibliographic coupling links.

\section{$<<$ Figure 6>>}

The results are consistent with those of Table 5 where the University of California Berkeley is by far the most productive university in the journal. Note that institutions from the same countries or regions tend to appear close to each other. Two main reasons could offer explanation to this finding: first, the co-authorship, implying that two authors present a similar citation profile; second, it is quite common that researchers from the same region tend to work on similar specific topics becoming particularly popular in that region.

Next, we have tried to generalize these results at country level, by using bibliographic coupling of countries. It is worth noting that the analysis of countries represents the author affiliation at the time of publication in Energy Efficiency. In Figure 7 we present the results considering a minimum publication threshold of two documents and the 50 strongest bibliographic coupling links.

$<<$ Figure 7>>

The United States of America appears as the country with the highest number of published articles in Energy Efficiency. However, its results are not so remarkable according 
to the country size. In fact, Figure 6 clearly visualizes the stronger influence played by European countries on the journal. Particularly, the results of Sweden and Netherlands, with higher figures by normalizing articles per capita, are notable.

Finally, we have analysed the most common keywords used in the journal, which provides a general orientation of the leading topics in Energy Efficiency. To do this, first we have studied co-occurrence of author keywords by counting the number of times a keyword appears in the list of keywords provided by the authors together with the abstract. Second, we have measured those keywords appearing more frequently in the same documents. Figure 8 presents the results considering a minimum threshold of three occurrences and the 100 strongest co-occurrence links.

\section{$<<$ Figure $8>>$}

Finding the keyword "energy efficiency" as the most popular one in the journal (Table 9) was somehow expected, given that it coincides with the name of the journal. But, our analysis allows to pinpoint some other keywords becoming significant in Energy Efficiency, including "energy savings", "energy consumption" and "demand response": these results are reasonable considering the partial overlap between them and the "energy efficiency" keyword. However, some additional interesting insights can be made. First, it is worth noting the so many connections between the keyword "energy efficiency" with others, confirming the multiple perspectives and applications covered within the journal. Second, there is a lack of a strong pattern for keywords: indeed, we can see multiple connections, but not clear clusters or independent aggregates of keywords, suggesting that, rather than pursuing consolidated research streams, the journal is addressing the energy efficiency issue throughout its multifaceted aspects. Being the journal at its early years, this finding appears as overall reasonable. Nevertheless, by further analysing keywords over the last five years, two of them stepped up, namely "demand response" and "smart grid". Interestingly, firstly demand response does barely appear in the rank of first 30 keywords for 2008-2012, whilst ranking fourth in the 2013-2017 rank. Secondly, the keyword smart grid does not even appear in the 2008-2012 30 keywords, whilst ranking fifth in the 2013-2017 one. Indeed, both keywords refer to relatively appealing young topics considered as crucial for current and 
future energy policies (EC, 2018), confirming that, for an improved energy efficiency at system level, further efforts should be paid by final users to better match the demand of power supply.

$<<$ Table 9>>

\section{Conclusions}

Energy Efficiency journal is ten years old. To celebrate this anniversary, the present article presents, through a bibliometric analysis using the WoS Core Collection and Scopus databases, the leading trends occurred in the journal of this first decade. We have based our considerations on a broad set of bibliometric indicators, as well as on a visualisation tool, that allowed to analyse results by creating a map of the bibliographic material, thus looking at most relevant connections between journals, topics, authors, institutions and keywords. The main advantage of this approach is that the work offers a complete picture of the current publication and citation structure of the journal and how it is positioning in the academic debate.

Results seem to show that the Energy Efficiency journal is finding its room in the scientific community, tackling the multifaceted and multidisciplinary aspects of energy

efficiency, from application research and innovation in various contexts, e.g., buildings or industry or transport, to "horizontal" topics, such as e.g., policy instruments, financing, smart meters, as well as behavior of final users.

Energy Efficiency aims at positioning itself at the core of the energy efficiency research and discussion, with strong connections with relevant other journals such as Energy Policy, Energy and Buildings, Energy, Energy Economics, Applied Energy, Renewable and Sustainable Energy Reviews, Energies, and Journal of Cleaner Production. Nevertheless, compared to other established and renowned journals, Energy Efficiency focuses on a narrower area of energy issue (i.e. energy efficiency) and explores it more in depth, by means of a multidisciplinary approach, taking benefits from consolidated disciplines such as psychology, economics, management and engineering.

Our analysis reveals that the journal hosts contributions to a well-diversified set of institutions and countries, although predominantly influenced by European scholars, but with 
growing number of contributions coming from developing economies such as China, Iran, Turkey, India and Brazil. Moreover, the bibliometric analysis shows interesting positive trends in both the number of manuscripts published per year as well as annual number of citations, especially from other journals.

To conclude, some future research avenues in the field can be sketched. The study, by showing the growing linkages between Energy Efficiency and other relevant journals, showcases that future coordinated efforts from different disciplines (technical, economic and socio-psychological ones) could be particularly interesting and effective to address the energy efficiency challenges and contribute to sustainable development. This is particularly evident by looking at the "energy efficiency first" approach proposed by the European Commission (EC, 2018): rather than promoting single specific actions, energy efficiency is looked as a compass to guide any decision-making. More specifically, the scope is quite large, as energy efficiency should be improved at all stages of the energy chain, from generation to final consumption. Interestingly, this requires not only further knowledge on the technological issues regarding the performance of equipment, but also improved knowledge over the issues affecting the energy efficiency value chain, as well as challenges for final users, as this analysis of the Energy Efficiency journal shows.

Increased multidisciplinary efforts should also address the so-many benefits from energy efficiency improvement: we can note that this topic is receiving greater and greater attention by scholars and policy-makers (e.g., Nehler, 2018; Nehler et al., 2018) but, in order to be pinpointed and quantified, deliberate and accurate consideration from many disciplines is of crucial importance. Related to this, future research about non-energy benefits could pave the way to further efforts in integrating energy efficiency improvements (and savings) within a carbon reduction framework, so more clearly express the contribution and leverage of energy efficiency to sustainable development and climate change mitigation, as prompted by one of the most cited manuscripts in this journal (Worrell et al., 2009).

Furthermore, future energy systems represent another field whose success is subject to multidisciplinary support and attention from academia, research and innovation centers. In fact, the evolution of smart grids seems so far subject to several key challenges, e.g. in Europe, such as regulatory barriers, technology maturity and consumer engagement (Iqtiyanillham et al., 2017; Hansen and Hauge, 2017). In parallel, recent research (e.g., Lund 
et al., 2014) is delving into new paradigms aimed to the integration of smart thermal grids into future sustainable energy systems. In both cases, as revealed from our findings, a valuable contribution, among others, could come from future research focusing on how to more effectively value energy efficiency as part of an evolving smarter grid and more sustainable energy system.

\section{References}

Alonso, S., Cabrerizo, F.J., Herrera-Viedma, E., \& Herrera, F. (2009). H-index: A review focused on its variants, computation, and standardization for different scientific fields. Journal of Informetrics, 3(4), 273-289.

Barker, T., Dagoumas, A., Rubin, J. (2009). The macroeconomic rebound effect and the world economy. Energy Efficiency, 2(4), 411-427.

Bergman, N., Eyre, N. (2011). What role for microgeneration in a shift to a low carbon domestic energy sector in the UK?, Energy Efficiency, 4(3), 335-353.

Bertoldi, P. (2008). Editorial. Energy Efficiency, 1(1), 1-3.

Bertoldi, P. Rezessy, S. (2008). Tradable white certificate schemes: fundamental concepts. Energy Efficiency, 1(4), 237-255.

Bertoldi, P., Rezessy, S., Oikonomou, V., (2013). Rewarding energy savings rather than energy efficiency: Exploring the concept of a feed-in tariff for energy savings. Energy Policy, 56, 526-535.

Bertoldi P., (2018). The Paris Agreement $1.5^{\circ} \mathrm{C}$ goal: what it does mean for energy efficiency?, In Proceedings of the 2018 ACEEE Summer Study on Energy Efficiency in Buildings.

Bertoldi, P. (2019). Editorial note. Energy Efficiency, 11(8), 1.

Bortoni, E.C., de Almeida, R.A., Carvalho, V., Augusto, N. (2008). Optimization of parallel variable-speed-driven centrifugal pumps operation. Energy Efficiency, 1(3), 167-173.

Brown, M.A., Matt Cox, P.B., Kim, Y.J. (2014). Evaluating the risks of alternative energy policies: a case study of industrial energy efficiency, Energy Efficiency, 7(1), 1-22.

Cagno, E., Worrell, E., Trianni, A., \& Pugliese, G. (2013). A novel approach for barriers to industrial energy efficiency. Renewable and Sustainable Energy Reviews, 19, 290-308.

Caird, S., Roy, R., Herring, H. (2008) Improving the energy performance of UK households: Results from surveys of consumer adoption and use of low- and zero-carbon technologies. Energy Efficiency, 1(2), 149-166.

Caird, S., Royt, R., Potter, S., (2012). Domestic heat pumps in the UK: user behaviour, satisfaction and performance. Energy Efficiency, 5(3), 283-301.

Cancino, C., Merigó, J.M., Coronado, F., Dessouky, Y., \& Dessouky, M. (2017). Forty years of Computers \& Industrial Engineering: A bibliometric analysis. Computers \& Industrial Engineering, 113, 614-629.

Cobo, M.J., Lopez-Herrera, A.G., Herrera-Viedma, E., \& Herrera, F. (2011). Science mapping software tools: Review, analysis and cooperative study among tools. Journal of the American Society for Information Science and Technology, 62(7), 1382-1402. 
Cobo, M.J., Martínez, M.A., Gutiérrez-Salcedo, M., Fujita, H., \& Herrera-Viedma, E. (2015). 25 years at Knowledge-Based Systems: A bibliometric analysis. Knowledge-Based Systems, 80, 3-13.

Cooremans, C. (2011). Make it strategic! Financial investment logic is not enough. Energy Efficiency, 4(4), 473-492.

Cooremans, C. (2012). Investment in energy efficiency: do the characteristics of investments matter?. Energy Efficiency, 5(4), 497-518.

Cooper A.M.G. (2018). Evaluating energy efficiency policy: understanding the 'energy policy epistemology' may explain the lack of demand for randomised controlled trials, Energy Efficiency, 11(4), 997-1008.

Ding, Y., Rousseau, R., \& Wolfram, D. (2014). Measuring scholarly impact: Methods and practice, Springer, Switzerland.

Du, H., Wei, L., Brown, M.A., Wang, Y., Shi, Z. (2013). A bibliometric analysis of recent energy efficiency literatures: an expanding and shifting focus. Energy Efficiency, 6(1), 177-190.

[EC] European Commission Statement (2018). Energy efficiency first: Commission welcomes agreement on energy efficiency. Available at: http://europa.eu/rapid/pressrelease_STATEMENT-18-3997_en.htm

[EIA] US Department of Energy/Energy Information Administration. Annual Energy Outlook, 2018. Available at: https://www.eia.gov/outlooks/aeo/

Fischer, C. (2008). Feedback on household electricity consumption: a tool for energy saving?. Energy Efficiency, 1(1), 79-104.

Geller, H., DeCicco, J., Laitner, S., Dyson, C. (1994). Twenty years after the embargo US oil import dependence and how it can be reduced, Energy Policy 22(6), 471-485.

Gram-Hanssen, K., (2013). Efficient technologies or user behaviour, which is the more important when reducing households' energy consumption?. Energy Efficiency, 6(3), 477-457.

Granderson, J., Piette, M.A., Ghatikar, G. (2011). Building energy information systems: user case studies. Energy Efficiency, 4(1), 17-30.

Gynther, L., Mikkonen, I., Smits, A. (2012). Evaluation of European energy behavioural change programmes. Energy Efficiency, 5(1), 67-82.

Grossman, P.Z. (2015). Energy shocks, crises and the policy process: A review of theory and application, Energy Policy, 77, 56-69,

Hansen, M., Hauge, B. (2017). Prosumers and smart grid technologies in Denmark: developing user competences in smart grid households. Energy Efficiency, 10(5), 12151234.

Hasanbeigi, A., Menke, C., duPont, P. (2010). Barriers to energy efficiency improvement and decision-making behavior in Thai industry. Energy Efficiency, 3(1), 33-52.

Harmelink, M., Nilsson, L., Harmsen, R. (2008) Theory-based policy evaluation of 20 energy efficiency instruments. Energy Efficiency, 1(2), 131-148.

Harvey, L.D.D. (2009). Reducing energy use in the buildings sector: measures, costs, and examples. Energy Efficiency, 2(2), 139-163.

Hirsch, J.E. (2005). An index to quantify an individual's scientific research output. Proceedings of the National Academy of Sciences of the United States of America, 102(46), 16569-16572.

Hirst, E., Brown, M.A., (1990). Closing the efficiency gap: barriers to the efficient use of energy. Resources, Conservation and Recycling, 3, 267-281. 
Iqtiyanillham, N., Hasanuzzaman, M., Hosenuzzaman, M. (2017). European smart grid prospects, policies and challenges. Renewable and Sustainable Energy Reviews, 67, 776790.

Jaffe, A.G., Stavins, R.N., (1994). The energy-efficiency gap What does it mean?, Energy Policy, 22(10), 804-810

Ji, L., Liu, C., Huang, L., \& Huang, G. (2018). The evolution of Resources Conservation and Recycling over the past 30 years: A bibliometric overview. Resources, Conservation \& Recycling, 134, 34-43.

Johansson, M.T., Söderstrom, M. (2014). Electricity generation from low-temperature industrial excess heat-an opportunity for the steel industry. Energy Efficiency, 7(2), 203215.

Kessler, M.M. (1963). Bibliographic coupling between scientific papers. American Documentation, 14(1), 10-25.

Kobayashi, S., Plotkin, S., Ribeiro, S.K. (2009). Energy efficiency technologies for road vehicles. Energy Efficiency, 2(2), 125-137.

Laengle, S., Merigó, J.M., Miranda, J., Slowinski, R., Bomze, I., Borgonovo, E., Dyson, R.G., Oliveira, J.F., \& Teunter, R. (2017). Forty years of the European Journal of Operational Research: A bibliometric overview. European Journal of Operational Research, 262(3), 803-816.

Laengle, S., Modak, N.M., Merigó, J.M., Zurita, G. (2018). Twenty-five years of Group Decision and Negotiation: A bibliometric overview. Group Decision and Negotiation, 27(4), 505-542.

Lechtenboehmer, S., Schuering, A. (2011). The potential for large-scale savings from insulating residential buildings in the EU. Energy Efficiency, 4(2), 257-270.

Levinson, R., Akbari, H. (2010) Potential benefits of cool roofs on commercial buildings: conserving energy, saving money, and reducing emission of greenhouse gases and air pollutants. Energy Efficiency, 3(1), 53-109.

Liang, Q.M., Fan, Y., Wei, Y.M. (2009). The effect of energy end-use efficiency improvement on China's energy use and $\mathrm{CO}_{2}$ emissions: a CGE model-based analysis. Energy Efficiency, 2(3), 243-262.

Lu, S-H, Lu, C., Tseng, K-T, Chen, F., Chen, C-L. (2013). Energy saving potential of the industrial sector of Taiwan. Renewable and Sustainable Energy Reviews, 21, 674-683.

Lund, H., Werner, S., Wiltshire, R., Svendsen, S., Thorsen, J.E., Hvelpund, F., Vad Mathiesen, B. (2014). 4th Generation District Heating (4GDH) Integrating smart thermal grids into future sustainable energy systems, Energy, 68, 1-11.

Mallaburn, P.S., Eyre, N. (2014). Lessons from energy efficiency policy and programmes in the UK from 1973 to 2013. Energy Efficiency, 7(1), 23-41.

Martínez-López, F.J., Merigó, J.M., Valenzuela, L., \& Nicolás, C. (2018). Fifty years of the European Journal of Marketing: A bibliometric analysis. European Journal of Marketing, 52(1-2), 439-468.

Merigó, J.M., Blanco-Mesa, F., Gil-Lafuente, A.M., \& Yager, R.R. (2017). Thirty years of the International Journal of Intelligent Systems: A bibliometric review. International Journal of Intelligent Systems, 32, 526-554.

Merigó, J.M., Gil-Lafuente, A.M., \& Yager, R.R. (2015). An overview of fuzzy research with bibliometrics indicators. Applied Soft Computing, 27, 420-433.

Merigó, J.M., Pedrycz, W., Weber, R., \& de la Sotta, C. (2018). Fifty years of Information Sciences: A bibliometric overview. Information Sciences, 432, 245-268. 
Merigó, J.M., \& Yang, J.B. (2017b). A bibliometric overview of operations research \& management science. Omega - International Journal of Management Science, 73, 3748.

Mills, E., (2011). Building commissioning: a golden opportunity for reducing energy costs and greenhouse gas emissions in the United States. Energy Efficiency, 4(2), 145-173.

Mogens R., From import dependence to self-sufficiency in Denmark, 1945-2000, Energy Policy, Volume 125,2019,Pages 82-89,

Murakami, S., Levine, M.D., Yoshino, H., Inoue, T., Ikaga, T., Shimoda, Y., Miura, S., Sera, T., Nishio, M., Sakamoto, y., Fujisaki, W. (2009) Overview of energy consumption and GHG mitigation technologies in the building sector of Japan. Energy Efficiency, 2(2), 178-194.

Nassen, J., Holmberg, J. (2009). Quantifying the rebound effects of energy efficiency improvements and energy conserving behaviour in Sweden. Energy Efficiency, 2(3), 221-231.

Nehler, T., (2018). Linking energy efficiency measures in industrial compressed air systems with non-energy benefits - A review. Renewable and Sustainable Energy Reviews, 89, 72-87.

Nehler, T., Parra, R., Thollander, P. (2018). Implementation of energy efficiency measures in compressed air systems: barriers, drivers and non-energy benefits. Energy Efficiency, 11(5), 1281-1302.

Nyborg, S., Ropke, I. (2013). Constructing users in the smart grid-insights from the Danish eFlex project. Energy Efficiency, 6(4), 655-670.

Pakula, C., Stamminger, R., (2010). Electricity and water consumption for laundry washing by washing machine worldwide. Energy Efficiency, 3(4), 365-382.

Palmer, K., Walls, M., Gordon, H., Gerarden, T. (2013). Assessing the energy-efficiency information gap: results from a survey of home energy auditors. Energy Efficiency, 6(2), 271-292.

Pierre, M., Jemelin, C., Louvet, N. (2011). Driving an electric vehicle. A sociological analysis on pioneer users. Energy Efficiency, 4(4), 511-522.

Ruzzenenti F., Bertoldi P. (2017) Energy Conservation Policies in the Light of the Energetics of Evolution. In: Labanca N. (eds) Complex Systems and Social Practices in Energy Transitions. Green Energy and Technology. Springer.

Schleich, J. Rogge, K., Betz, R., (2009), Incentives for energy efficiency in the EU Emissions Trading Scheme. Energy Efficiency, 2(1), 37-67.

Schneider, U.A., Smith, P. (2009). Energy intensities and greenhouse gas emission mitigation in global agriculture. Energy Efficiency, 2(2), 195-206.

Sorove, K.L., Nilsson, L.J. (2010). Building a business to close the efficiency gap: the Swedish ESCO Experience. Energy Efficiency, 3(3), 237-256.

Sorrell, S., O'Malley, E., Schleich, J. \& Scott, S. (2004). The economics of energy efficiency. Cheltenham, UK: Edward Elgar Publishing p. 349.

Stenqvist, C., Nilsson, L.J. (2012). Energy efficiency in energy-intensive industries-an evaluation of the Swedish voluntary agreement PFE. Energy Efficiency, 5(2), 225-241.

Thollander, P., Danestig, M., Rohdin, P. (2007). Energy policies for increased industrial energy efficiency: Evaluation of a local energy programme for manufacturing SMEs. Energy Policy, 35, 5774-5783. 
Thollander, P., Ottosson, M. (2008). An energy efficient Swedish pulp and paper industry exploring barriers to and driving forces for cost-effective energy efficiency investments. Energy Efficiency, 1(1), 21-34.

Tur-Porcar, A., Mas-Tur, A., Merigó, J.M., Roig-Tierno, N., \& Watt, J. (2018). A bibliometric history of the Journal of Psychology between 1936 and 2015. Journal of Psychology, 152, 199-225.

Uerge-Vorsatz, D., Novikova, A., Koeppe, S, Boza-Kiss, B. (2009). Bottom-up assessment of potentials and costs of $\mathrm{CO} 2$ emission mitigation in the buildings sector: insights into the missing elements. Energy Efficiency, 2(4),293-316.

Valenzuela, L., Merigó, J.M., Johnston, W., Nicolás, C. \& Jaramillo, F. (2017). Thirty years of the Journal of Business \& Industrial Marketing: A bibliometric analysis. Journal of Business \& Industrial Marketing, 32(1), 1-18.

Van Eck, N.J., \& Waltman, L. (2010). Software survey: VOSviewer, a computer program for bibliometric mapping. Scientometrics, 84(2), 523-538.

Vine, E. (2008). Breaking down the silos: the integration of energy efficiency, renewable energy, demand response and climate change. Energy Efficiency, 1(1), 49-63.

Wang, W., Laengle, S., Merigó, J.M., Yu, D., Herrera-Viedma, E., Cobo, M.J., \& BouchonMeunier, B. (2018). A bibliometric analysis of the first twenty-five years of the International Journal of Uncertainty, Fuzziness and Knowledge-Based Systems. International Journal of Uncertainty, Fuzziness and Knowledge-Based Systems, 26, $169-193$.

Wilhite, H., (2008). New thinking on the agentive relationship between end-use technologies and energy-using practices. Energy Efficiency, 1(2),121-130.

Worrell, E., Bernstein, L., Roy, J, Price, L., Harnisch, J. (2009). Industrial energy efficiency and climate change mitigation. Energy Efficiency, 2(2), 109-123.

Wu, A.H., Cao, Y.Y. Liu, B. (2014). Energy efficiency evaluation for regions in China: an application of DEA and Malmquist indices. Energy Efficiency, 7(3), 429-439.

$\mathrm{Yu}, \mathrm{H}$; Pan, SY; Tang, BJ; et al. (2015). Urban energy consumption and CO2 emissions in Beijing: current and future. Energy Efficiency, 8(3), 527-543.

Yu, D., Xu, Z. S., Pedrycz, W., \& Wang, W. R. (2017). Information Sciences 1968-2016: A retrospective analysis with text mining and bibliometric. Information Sciences, 418-419, 619-634.

Yu, D., Xu, Z.S., Kao, Y., \& Lin, C.T. (2018). The structure and citation landscape of IEEE Transactions on Fuzzy Systems (1994-2015). IEEE Transactions on Fuzzy Systems, 26(2), 430-442.

$\mathrm{Yu}, \mathrm{D} ., \mathrm{Xu}, \mathrm{Z} . S .$, \& Fujita, H. (2018). Bibliometric analysis on the evolution of Applied Intelligence. Applied Intelligence, https://doi.org/10.1007/s10489-018-1278-z

Zou, H.Y., Du, H.B., Wang, Y., Zhao, L., Mao, G., Zuo, J., Liu, Y., Liu, X., \& Huisingh, D. (2017). A review of the first twenty-three years of articles published in the Journal of Cleaner Production: With a focus on trends, themes, collaboration networks, low/nofossil carbon transformations and the future. Journal of Cleaner Production, 163, 1-14. 


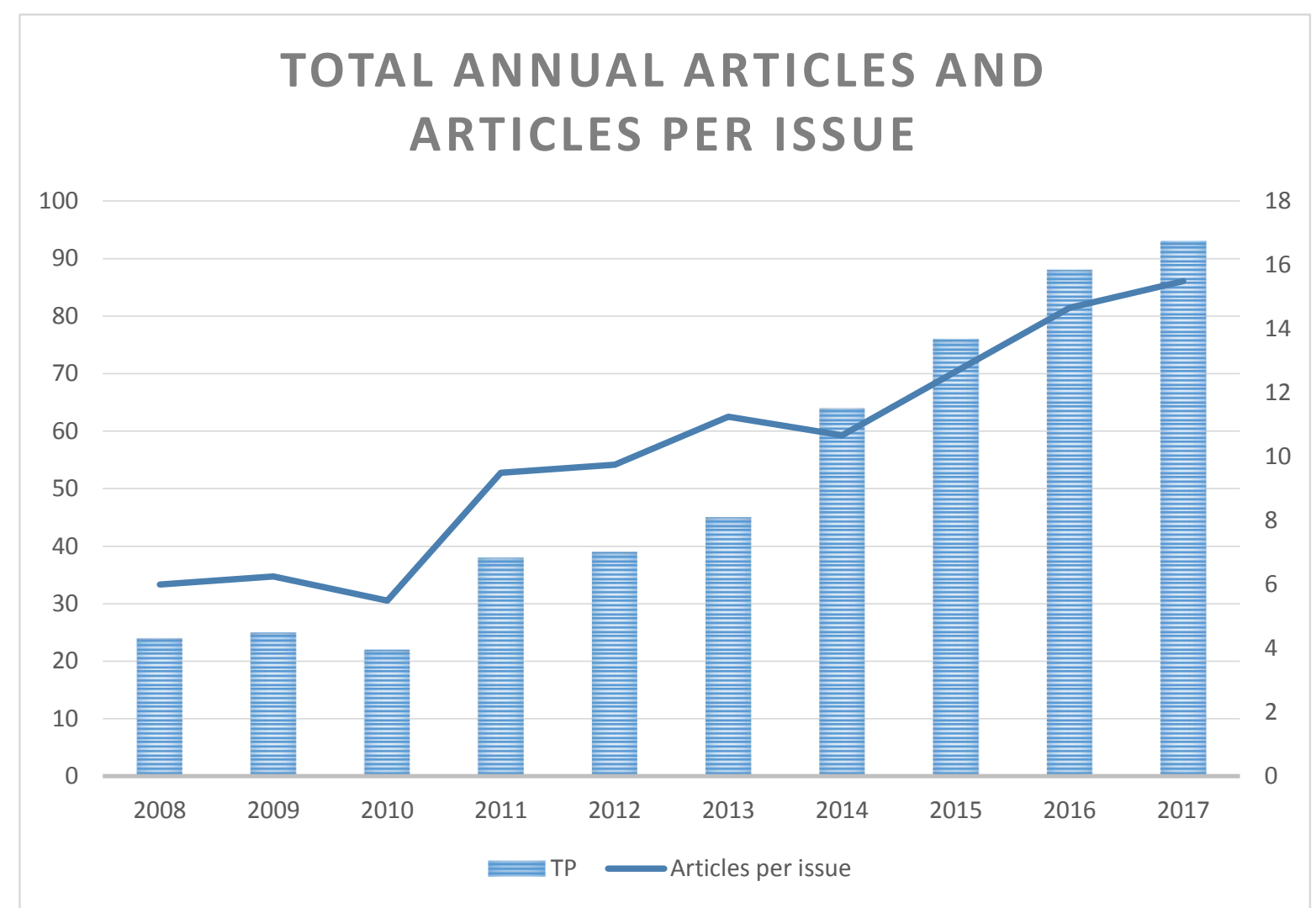

Figure 1. Annual number of papers published in Energy Efficiency 
2008-2017 Energy Efficiency manuscript submissions, accepted manuscripts and downloads

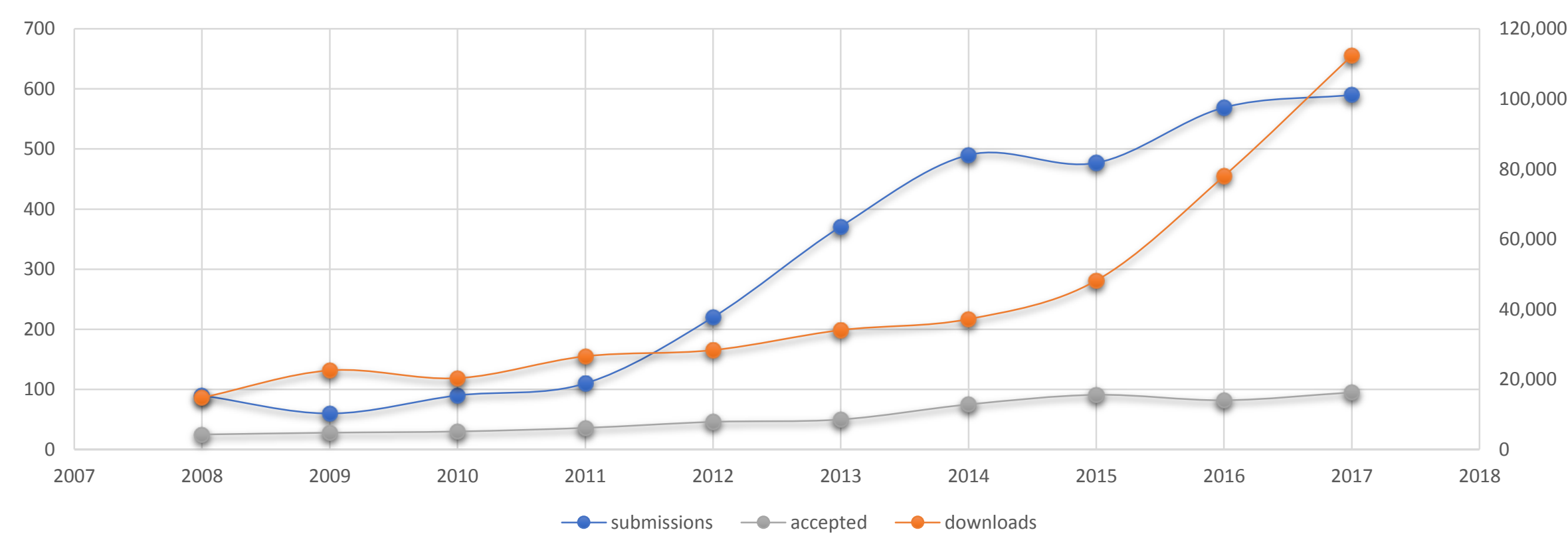

Figure 2. Annual number of manuscripts submitted and downloaded in Energy Efficiency journal. 
30

10

0

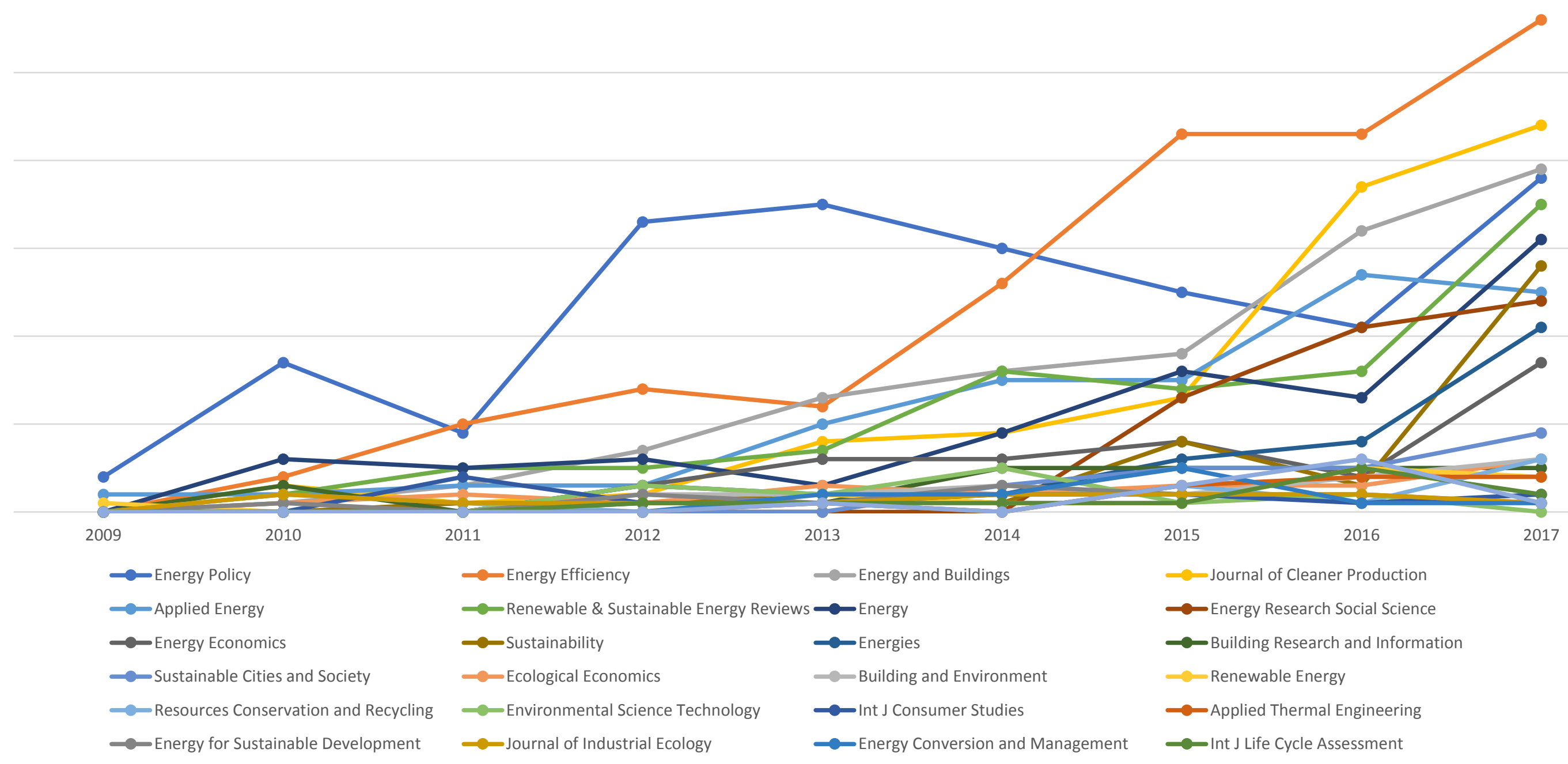

-Tenside Surfactants Detergents

Figure 3. Annual number of manuscripts citing Energy Efficiency journal 


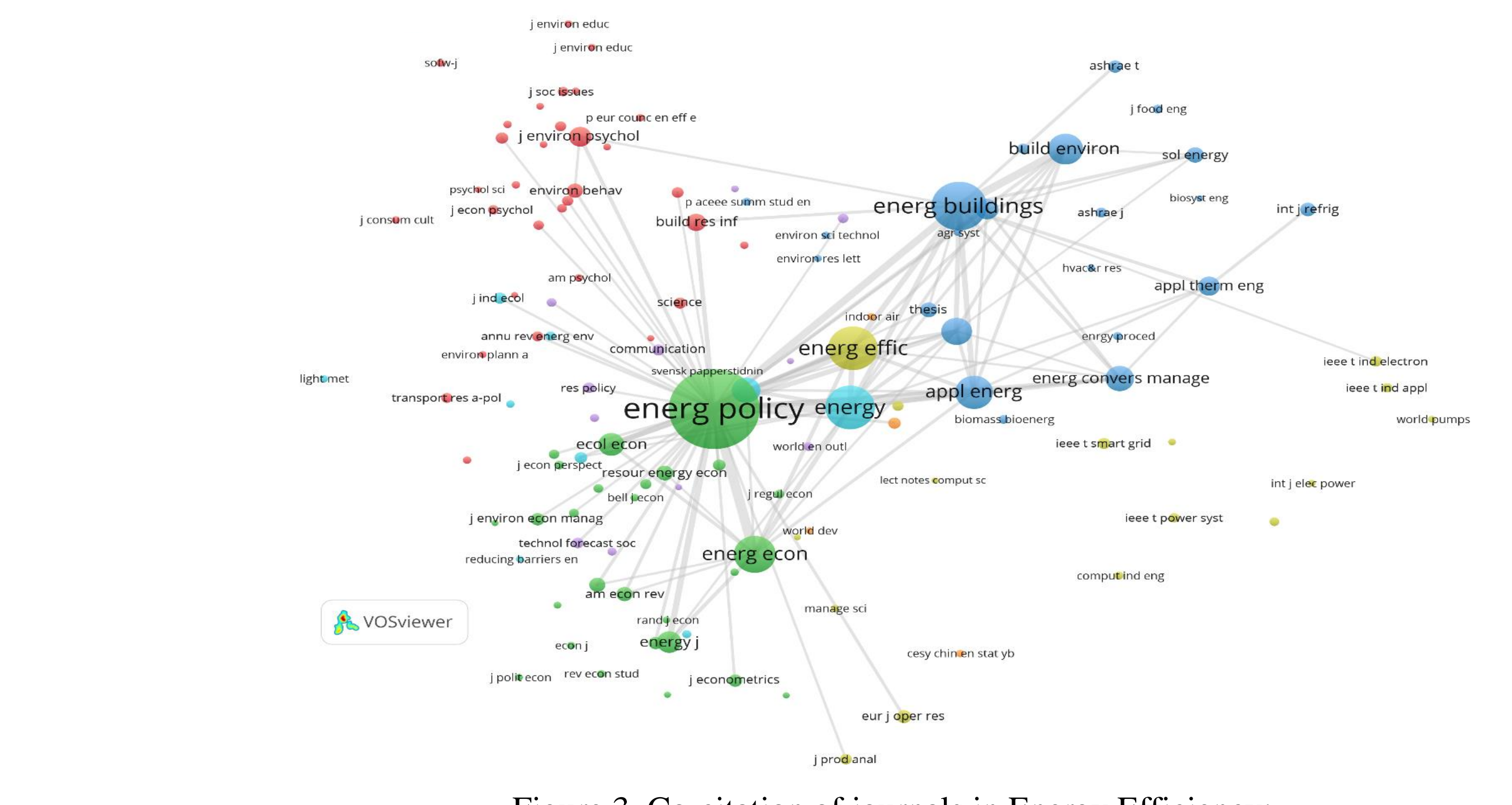

Figure 3. Co-citation of journals in Energy Efficiency:

\author{
minimum citation threshold of 10 and 100 links

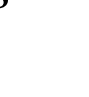

20.

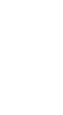




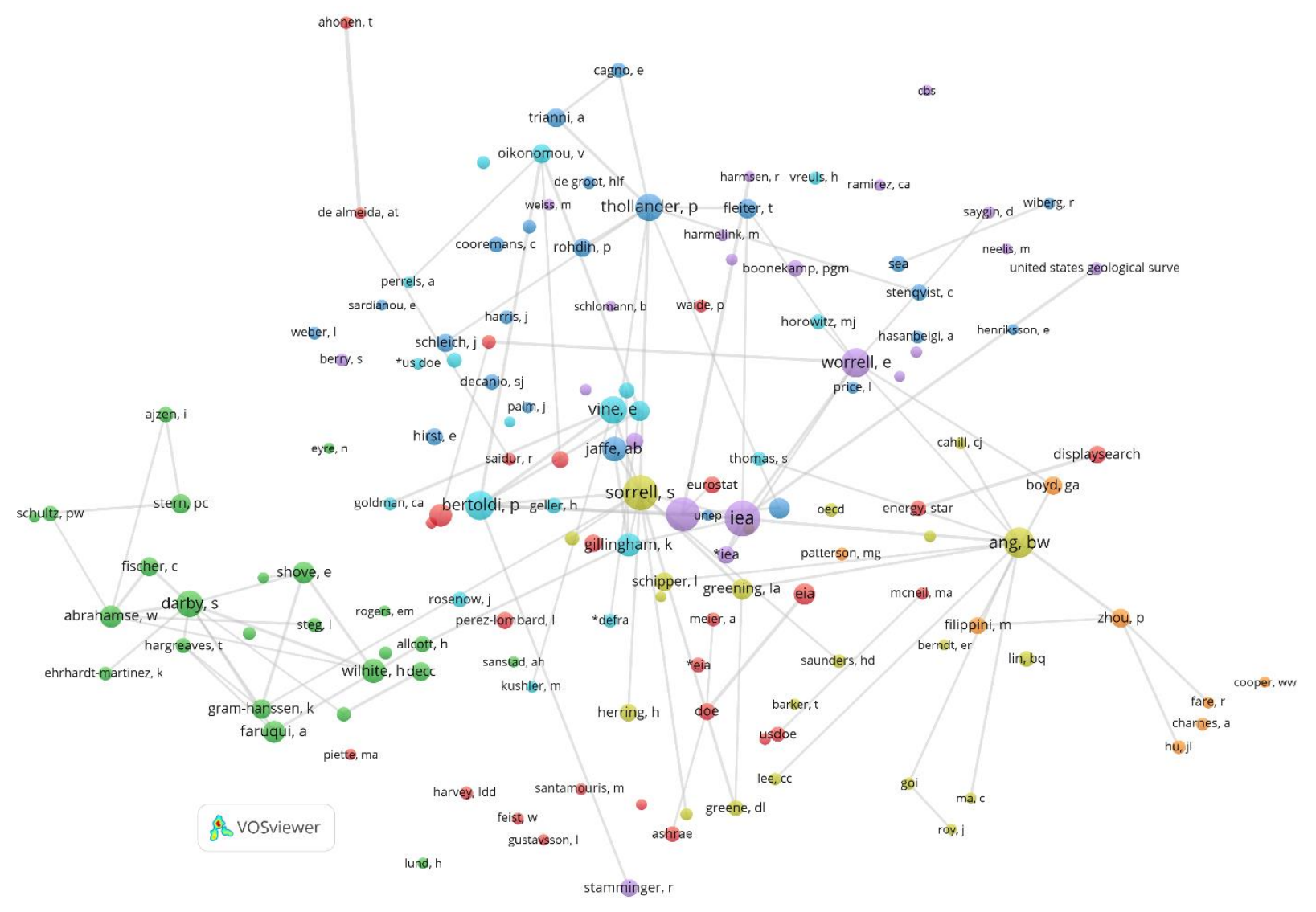

Figure 4. Co-citation of authors in EF: minimum citation threshold of 10 and 100 links 


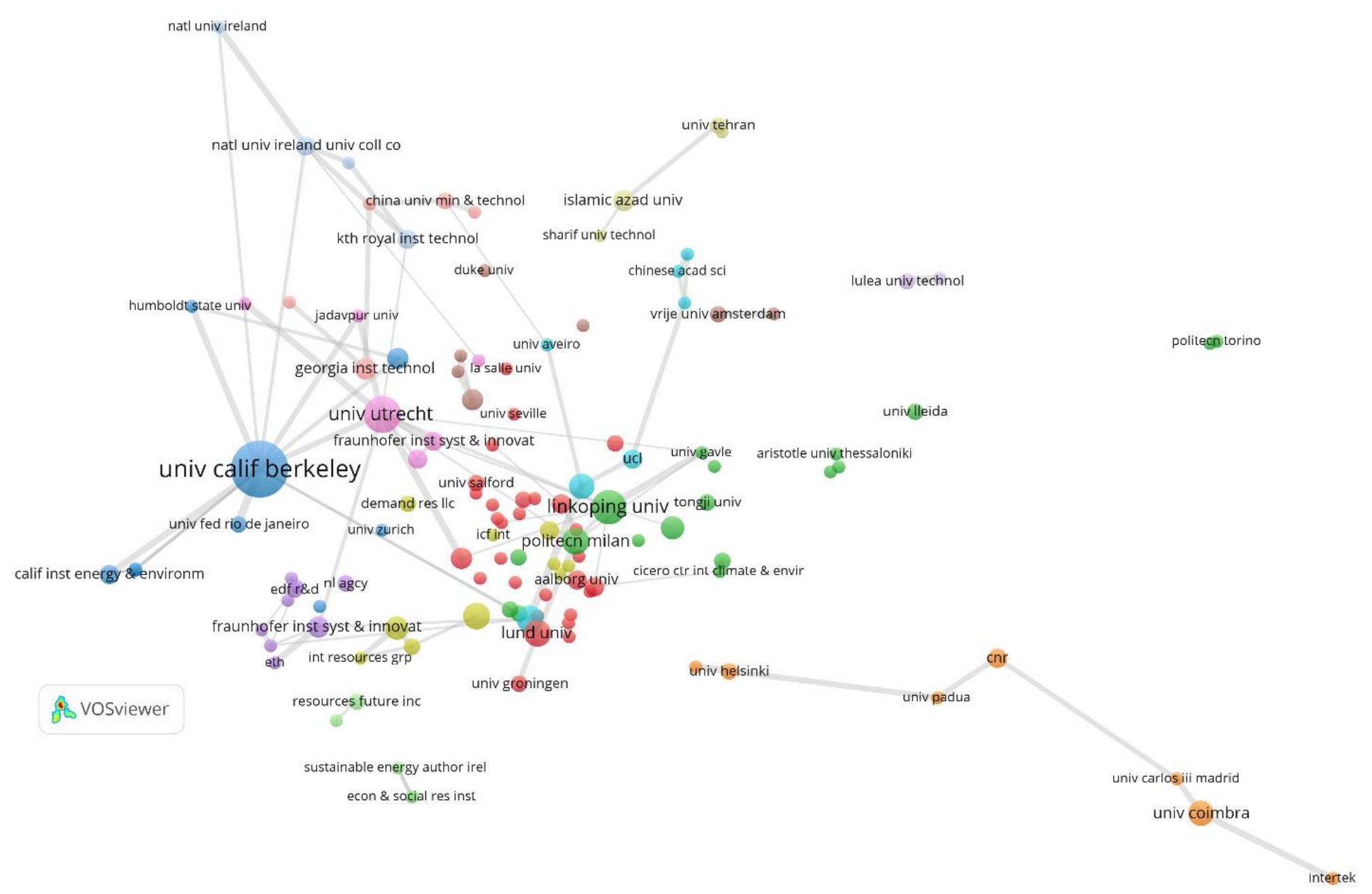

Figure 5. Bibliographic coupling of institutions publishing in Energy Efficiency: minimum publication threshold of 2 documents and 100 links 


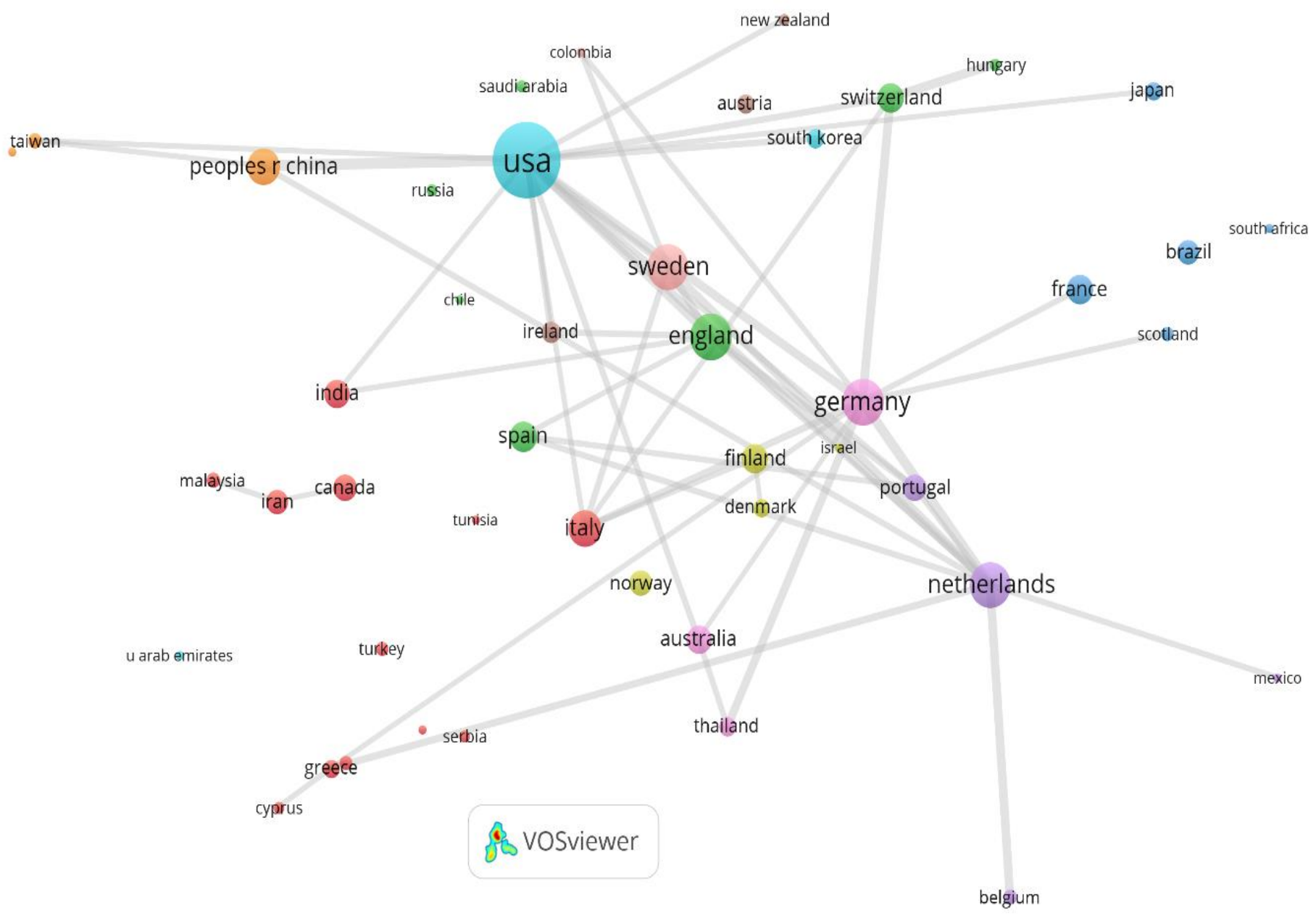

Figure 6. Bibliographic coupling of countries publishing in

Energy Efficiency: minimum publication threshold of 2 documents and 50 links 


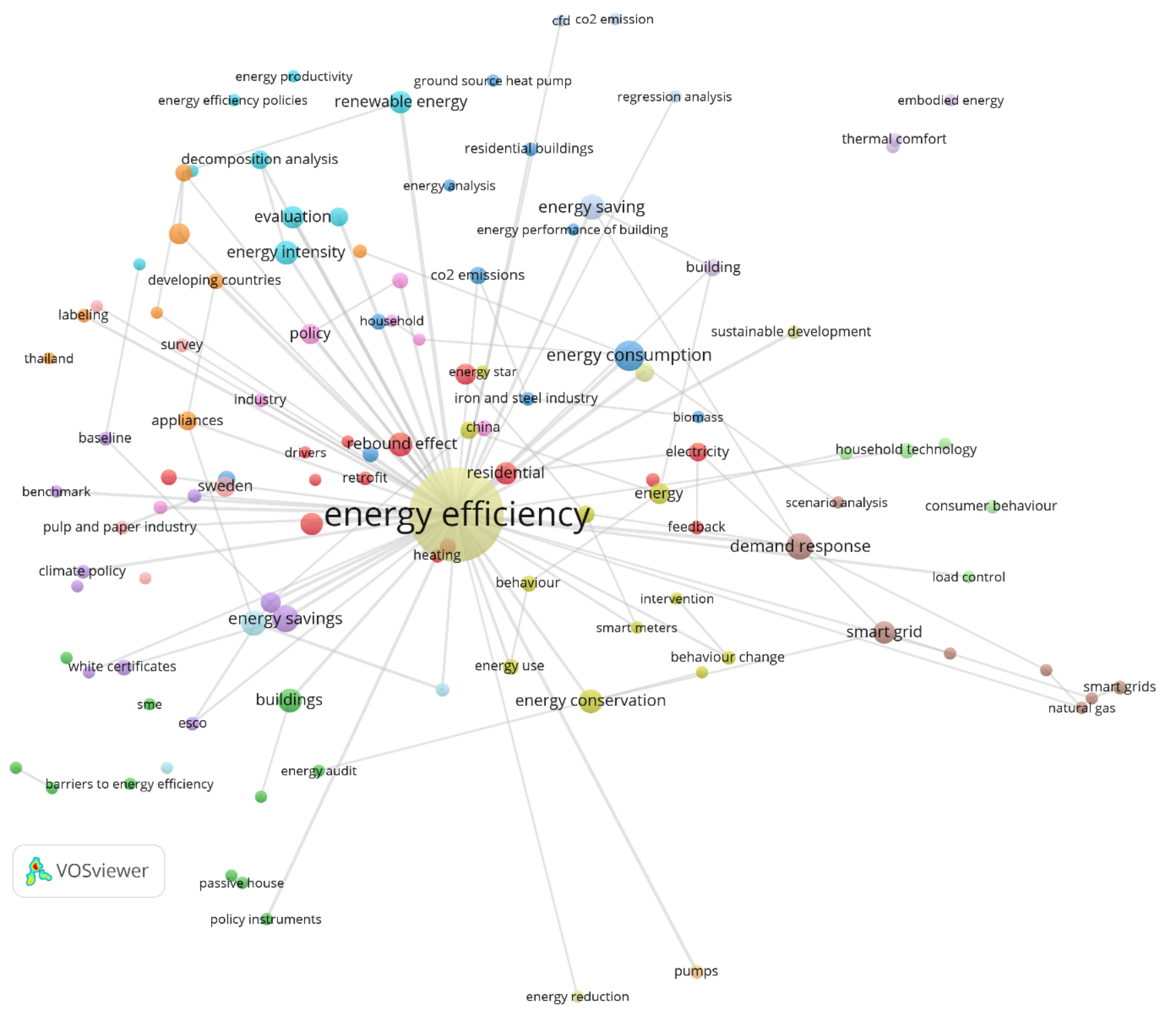

Figure 7. Co-occurrence of author keywords in Energy

Efficiency: minimum occurrence threshold of 3 and 100 links 
Table 1. Annual citation structure of Energy Efficiency

\begin{tabular}{ccccccccc}
\hline Year & TP & TC & $\geq 100$ & $\geq 50$ & $\geq 25$ & $\geq 10$ & $\geq 5$ & $\geq 1$ \\
\hline 2008 & 24 & 958 & 2 & 3 & 8 & 13 & 20 & 22 \\
2009 & 25 & 629 & 1 & 3 & 10 & 17 & 21 & 24 \\
2010 & 22 & 308 & 0 & 2 & 4 & 6 & 14 & 21 \\
2011 & 38 & 491 & 0 & 0 & 7 & 18 & 26 & 37 \\
2012 & 39 & 360 & 0 & 0 & 5 & 12 & 22 & 35 \\
2013 & 45 & 438 & 0 & 0 & 5 & 18 & 28 & 39 \\
2014 & 64 & 437 & 0 & 0 & 3 & 13 & 32 & 53 \\
2015 & 76 & 311 & 0 & 0 & 2 & 7 & 17 & 52 \\
2016 & 88 & 206 & 0 & 0 & 0 & 0 & 10 & 44 \\
2017 & 93 & 94 & 0 & 0 & 0 & 0 & 1 & 20 \\
\hline Total & 514 & & 3 & 8 & 44 & 104 & 191 & 347 \\
\hline$\%$ & $100.00 \%$ & & $0.58 \%$ & $1.56 \%$ & $8.56 \%$ & $20.23 \%$ & $37.16 \%$ & $67.51 \%$ \\
\hline
\end{tabular}

Abbreviations: TP and TC $=$ Total papers and citations; $\geq 100, \geq 50, \geq 25, \geq 10, \geq 5, \geq 1=$ Number of papers with equal or more than $100,50,25,10,5$ and 1 citations. 


\section{Table 2. The 40 most cited documents in Energy Efficiency according to WoS}

\begin{tabular}{|c|c|c|c|c|c|}
\hline $\mathrm{R}$ & $\mathrm{TC}$ & Title & Author/s & Year & $\begin{array}{l}\text { Citations } \\
\text { per year }\end{array}$ \\
\hline 1 & 450 & Feedback on household electricity consumption: a tool for saving energy? & Fischer, C & 2008 & 45.00 \\
\hline 2 & 134 & Industrial energy efficiency and climate change mitigation & $\begin{array}{l}\text { Worrell, E; Bernstein, L; Roy, J; } \\
\text { et al. }\end{array}$ & 2009 & 14.89 \\
\hline 3 & 118 & $\begin{array}{l}\text { An energy efficient Swedish pulp and paper industry - exploring barriers to and driving forces for } \\
\text { cost-effective energy efficiency investments }\end{array}$ & Thollander, P; Ottosson, M & 2008 & 11.80 \\
\hline 4 & 76 & Reducing energy use in the buildings sector: measures, costs, and examples & Harvey, LDD & 2009 & 8.44 \\
\hline 5 & 73 & The macroeconomic rebound effect and the world economy & $\begin{array}{l}\text { Barker, T; Dagoumas, A; Rubin, } \\
\text { J }\end{array}$ & 2009 & 8.11 \\
\hline 6 & 73 & $\begin{array}{l}\text { Improving the energy performance of UK households: Results from surveys of consumer adoption } \\
\text { and use of low- and zero-carbon technologies }\end{array}$ & Caird, S; Roy, R; Herring, H & 2008 & 7.30 \\
\hline 7 & 67 & $\begin{array}{l}\text { Potential benefits of cool roofs on commercial buildings: conserving energy, saving money, and } \\
\text { reducing emission of greenhouse gases and air pollutants }\end{array}$ & Levinson, R; Akbari, H & 2010 & 8.38 \\
\hline 8 & 54 & Electricity and water consumption for laundry washing by washing machine worldwide & Pakula, C; Stamminger, R & 2010 & 6.75 \\
\hline 9 & 48 & What role for microgeneration in a shift to a low carbon domestic energy sector in the UK? & Bergman, N; Eyre, N & 2011 & 6.86 \\
\hline 10 & 46 & Barriers to energy efficiency improvement and decision-making behavior in Thai industry & $\begin{array}{l}\text { Hasanbeigi, A; Menke, C; du } \\
\text { Pont, P }\end{array}$ & 2010 & 5.75 \\
\hline 11 & 44 & New thinking on the agentive relationship between end-use technologies and energy-using practices & Wilhite, H & 2008 & 4.40 \\
\hline 12 & 42 & Investment in energy efficiency: do the characteristics of investments matter? & Cooremans, $\mathrm{C}$ & 2012 & 7.00 \\
\hline 13 & 39 & $\begin{array}{l}\text { Energy efficiency in energy-intensive industries-an evaluation of the Swedish voluntary agreement } \\
\text { PFE }\end{array}$ & Stenqvist, C; Nilsson, LJ & 2012 & 6.50 \\
\hline 14 & 39 & Energy efficiency technologies for road vehicles & $\begin{array}{l}\text { Kobayashi, S; Plotkin, S; } \\
\text { Ribeiro, SK }\end{array}$ & 2009 & 4.33 \\
\hline 15 & 36 & Theory-based policy evaluation of 20 energy efficiency instruments & $\begin{array}{l}\text { Harmelink, M; Nilsson, L; } \\
\text { Harmsen, R }\end{array}$ & 2008 & 3.60 \\
\hline 16 & 35 & $\begin{array}{l}\text { Breaking down the silos: the integration of energy efficiency, renewable energy, demand response } \\
\text { and climate change }\end{array}$ & Vine, E & 2008 & 3.50 \\
\hline 17 & 34 & Make it strategic! Financial investment logic is not enough & Cooremans, $\mathrm{C}$ & 2011 & 4.86 \\
\hline 18 & 34 & $\begin{array}{l}\text { Bottom-up assessment of potentials and costs of } \mathrm{CO} 2 \text { emission mitigation in the buildings sector: } \\
\text { insights into the missing elements }\end{array}$ & $\begin{array}{l}\text { Uerge-Vorsatz, D; Novikova, A; } \\
\text { Koeppel, S; et al. }\end{array}$ & 2009 & 3.78 \\
\hline 19 & 33 & Constructing users in the smart grid-insights from the Danish eFlex project & Nyborg, S; Ropke, I & 2013 & 6.60 \\
\hline 20 & 33 & Energy intensities and greenhouse gas emission mitigation in global agriculture & Schneider, UA; Smith, P & 2009 & 3.67 \\
\hline 21 & 32 & $\begin{array}{l}\text { Efficient technologies or user behaviour, which is the more important when reducing households' } \\
\text { energy consumption? }\end{array}$ & Gram-Hanssen, K & 2013 & 6.40 \\
\hline 22 & 32 & The potential for large-scale savings from insulating residential buildings in the EU & $\begin{array}{l}\text { Lechtenboehmer, S; Schuering, } \\
\text { A }\end{array}$ & 2011 & 4.57 \\
\hline 23 & 32 & $\begin{array}{l}\text { Quantifying the rebound effects of energy efficiency improvements and energy conserving } \\
\text { behaviour in Sweden }\end{array}$ & Nassen, J; Holmberg, J & 2009 & 3.56 \\
\hline 24 & 39 & Lessons from energy efficiency policy and programmes in the UK from 1973 to 2013 & Mallaburn, PS; Eyre, N & 2014 & 9.75 \\
\hline 25 & 29 & $\begin{array}{l}\text { Building commissioning: a golden opportunity for reducing energy costs and greenhouse gas } \\
\text { emissions in the United States }\end{array}$ & Mills, E & 2011 & 4.14 \\
\hline 26 & 29 & Optimization of parallel variable-speed-driven centrifugal pumps operation & $\begin{array}{l}\text { Bortoni, EC; de Almeida, RA; } \\
\text { Carvalho V, Augusto N }\end{array}$ & 2008 & 2.90 \\
\hline 27 & 27 & Assessing the energy-efficiency information gap: results from a survey of home energy auditors & $\begin{array}{l}\text { Palmer, K; Walls, M; Gordon, } \\
\text { H; et al. }\end{array}$ & 2013 & 5.40 \\
\hline 28 & 27 & Building energy information systems: user case studies & $\begin{array}{l}\text { Granderson, J; Piette, MA; } \\
\text { Ghatikar, G }\end{array}$ & 2011 & 3.86 \\
\hline 29 & 25 & Urban energy consumption and $\mathrm{CO} 2$ emissions in Beijing: current and future & Yu, H; Pan, SY; Tang, BJ; et al. & 2015 & 8.33 \\
\hline 30 & 25 & Evaluation of European energy behavioural change programmes & $\begin{array}{l}\text { Gynther, L; Mikkonen, I; Smits, } \\
\text { A }\end{array}$ & 2012 & 4.17 \\
\hline 31 & 25 & Driving an electric vehicle. A sociological analysis on pioneer users & $\begin{array}{l}\text { Pierre, M; Jemelin, C; Louvet, } \\
\mathrm{N}\end{array}$ & 2011 & 3.57 \\
\hline 32 & 25 & Building a business to close the efficiency gap: the Swedish ESCO Experience & Soroye, KL; Nilsson, LJ & 2010 & 3.13 \\
\hline 33 & 25 & Incentives for energy efficiency in the EU Emissions Trading Scheme & Schleich, J; Rogge, K; Betz, R & 2009 & 2.78 \\
\hline 34 & 25 & Tradable white certificate schemes: fundamental concepts & Bertoldi, P; Rezessy, S & 2008 & 2.50 \\
\hline 35 & 24 & $\begin{array}{l}\text { The effect of energy end-use efficiency improvement on China's energy use and CO2 emissions: a } \\
\text { CGE model-based analysis }\end{array}$ & Liang, QM; Fan, Y; Wei, YM & 2009 & 2.67 \\
\hline 36 & 23 & Energy efficiency evaluation for regions in China: an application of DEA and Malmquist indices & Wu, AH; Cao, YY; Liu, B & 2014 & 5.75 \\
\hline 37 & 23 & $\begin{array}{l}\text { Electricity generation from low-temperature industrial excess heat-an opportunity for the steel } \\
\text { industry }\end{array}$ & Johansson, MT; Soderstrom, M & 2014 & 5.75 \\
\hline 38 & 23 & A bibliometric analysis of recent energy efficiency literatures: an expanding and shifting focus & $\begin{array}{l}\text { Du, H; Wei, L; Brown, MA.; et } \\
\text { al. }\end{array}$ & 2013 & 4.60 \\
\hline 39 & 23 & Domestic heat pumps in the UK: user behaviour, satisfaction and performance & Caird, S; Roy, R; Potter, S & 2012 & 3.83 \\
\hline 40 & 23 & Overview of energy consumption and GHG mitigation technologies in the building sector of Japan & $\begin{array}{l}\text { Murakami, S; Levine, MD; } \\
\text { Yoshino, H; et al. }\end{array}$ & 2009 & 2.56 \\
\hline
\end{tabular}

Abbreviations: $\mathrm{R}=$ Rank. 
Table 3. Top 30 most cited documents in Energy Efficiency publications

\begin{tabular}{|c|c|c|c|c|c|c|c|c|}
\hline Rank & Year & First author & Reference & Vol & Page & Type & $\mathrm{TC}$ & $\begin{array}{l}\text { Co- } \\
\text { citations }\end{array}$ \\
\hline 1 & 1994 & Jaffe AB & Energ Policy & v22 & $\mathrm{p} 804$ & $\mathrm{~A}$ & 26 & 23 \\
\hline 2 & 2000 & Greening LA & Energ Policy & v28 & p389 & A & 25 & 25 \\
\hline 3 & 2005 & Abrahamse W & J Environ Psychol & v25 & p273 & A & 24 & 23 \\
\hline 4 & 2008 & Fischer C & Energ Effic & $\mathrm{v} 1$ & p79 & A & 18 & 18 \\
\hline 5 & 2006 & Darby S & $\begin{array}{l}\text { Effectiveness of Feedback on } \\
\text { Energy Consumption }\end{array}$ & - & - & B & 17 & 16 \\
\hline 6 & 2009 & Sorrell S & Energ Policy & v37 & p1356 & A & 17 & 17 \\
\hline 7 & 2008 & Thollander P & Energ Effic & $\mathrm{v} 1$ & p21 & A & 16 & 16 \\
\hline 8 & 1990 & Hirst E & Resour Conserv Recy & v3 & p267 & A & 14 & 14 \\
\hline 9 & 2001 & De Groot HLF & Energ Econ & v23 & p717 & A & 13 & 13 \\
\hline 10 & 2006 & Rohdin P & Energy & v31 & p1836 & A & 12 & 12 \\
\hline 11 & 2007 & Rohdin P & Energ Policy & v35 & p672 & A & 12 & 12 \\
\hline 12 & 2003 & Worrell E & Energy & v28 & p1081 & A & 12 & 11 \\
\hline 13 & 2006 & Gillingham K & Annu Rev Env Resour & v31 & p161 & A & 11 & 11 \\
\hline 14 & 2008 & Perez-Lombard L & Energ Buildings & $\mathrm{v} 40$ & p394 & A & 11 & 6 \\
\hline 15 & 2012 & Stenqvist $\mathrm{C}$ & Energ Effic & v5 & p225 & A & 11 & 11 \\
\hline 16 & 2007 & Thollander P & Energ Policy & v35 & p5774 & A & 11 & 11 \\
\hline 17 & 1997 & Weber L & Energ Policy & v25 & p833 & A & 11 & 10 \\
\hline 18 & 1991 & Ajzen I & Organ Behav Hum Dec & v50 & p179 & A & 10 & 9 \\
\hline 19 & 2000 & Ang BW & Energy & v25 & p1149 & A & 10 & 10 \\
\hline 20 & 1996 & Patterson MG & Energ Policy & v24 & p377 & A & 10 & 9 \\
\hline 21 & 2000 & Sorrell S & $\begin{array}{l}\text { Reducing Barriers to Energy } \\
\text { Effic }\end{array}$ & - & - & B & 10 & 10 \\
\hline 22 & 2000 & Stern PC & J Soc Issues & v56 & $\mathrm{p} 407$ & A & 10 & 9 \\
\hline 23 & 2008 & Zhou P & Energ Policy & v36 & p2911 & A & 10 & 10 \\
\hline 24 & 2012 & Allcott $\mathrm{H}$ & J Econ Perspect & v26 & p3 & A & 9 & 9 \\
\hline 25 & 2004 & Ang BW & Energ Policy & v32 & p1131 & A & 9 & 9 \\
\hline 26 & 2001 & Binswanger $\mathrm{M}$ & Ecol Econ & v36 & p119 & A & 9 & 9 \\
\hline 27 & 2000 & Harris $\mathrm{J}$ & Energ Policy & v28 & p867 & A & 9 & 9 \\
\hline 28 & 1994 & Jaffe AB & Resour Energy Econ & v16 & p91 & A & 9 & 9 \\
\hline 29 & 2004 & Sorrell S & $\begin{array}{l}\text { Economics of Energy } \\
\text { Efficiency }\end{array}$ & - & - & B & 9 & 9 \\
\hline 30 & 2004 & Anderson ST & Resour Energy Econ & v26 & p27 & A & 8 & 8 \\
\hline
\end{tabular}

Abbreviations: $\mathrm{Vol}=$ Volume; $\mathrm{TC}=$ Total citations . 
Table 4. Leading authors in Energy Efficiency

\begin{tabular}{|c|c|c|c|c|c|c|c|c|}
\hline $\mathrm{R}$ & FULL NAME & University & TP & TC & $\mathrm{H}$ & $\mathrm{C} / \mathrm{P}$ & $>50$ & $>10$ \\
\hline 1 & Ernst Worrell & U Utrecht & 10 & 200 & 6 & 20.00 & 1 & 4 \\
\hline 2 & Rainer Stamminger & U Bonn & 7 & 91 & 4 & 13.00 & 1 & 3 \\
\hline 3 & Edward Vine & U California Berkeley & 7 & 68 & 5 & 9.71 & 0 & 2 \\
\hline 4 & Marilyn A. Brown & Georgia Institute of Technology & 5 & 38 & 3 & 7.60 & 0 & 1 \\
\hline 5 & Wolfgang Eichhammer & U Utrecht & 5 & 33 & 4 & 6.60 & 0 & 1 \\
\hline 6 & Robert Harmsen & U Utrecht & 5 & 45 & 2 & 9.00 & 0 & 1 \\
\hline 7 & Evan Mills & U California Berkeley & 5 & 56 & 3 & 11.20 & 0 & 2 \\
\hline 8 & Amol Phadke & U California Berkeley & 5 & 9 & 2 & 1.80 & 0 & 0 \\
\hline 9 & Tero Ahonen & Lappeenranta U Technology & 4 & 29 & 2 & 7.25 & 0 & 1 \\
\hline 10 & Semida Silveira & KTH Royal Inst Technology & 4 & 28 & 3 & 7.00 & 0 & 1 \\
\hline 11 & Jussi Tamminen & Lappeenranta U Technology & 4 & 29 & 2 & 7.25 & 0 & 1 \\
\hline 12 & Jero Ahola & Lappeenranta U Technology & 3 & 28 & 2 & 9.33 & 0 & 1 \\
\hline 13 & Morgan Bazilian & Colorado School of Mines & 3 & 26 & 3 & 8.67 & 0 & 1 \\
\hline 14 & Stephen Berry & U South Australia & 3 & 21 & 2 & 7.00 & 0 & 1 \\
\hline 15 & Jean-Sebastien Broc & Broc Res \& Consulting & 3 & 11 & 2 & 3.67 & 0 & 0 \\
\hline 16 & Luisa F. Cabeza & U Lleida & 3 & 19 & 3 & 6.33 & 0 & 0 \\
\hline 17 & Caiman J. Cahill & U College Cork & 3 & 21 & 3 & 7.00 & 0 & 0 \\
\hline 18 & Albert Castell & U Lleida & 3 & 19 & 3 & 6.33 & 0 & 0 \\
\hline 19 & Catherine Cooremans & U Lausanne & 3 & 76 & 2 & 25.33 & 0 & 2 \\
\hline 20 & Anibal T. de Almeida & U Coimbra & 3 & 16 & 2 & 5.33 & 0 & 1 \\
\hline 21 & Louis-Benoit Desroches & U California Berkeley & 3 & 4 & 1 & 1.33 & 0 & 0 \\
\hline 22 & Sally M. Donovan & Imperial College London & 3 & 4 & 1 & 1.33 & 0 & 0 \\
\hline 23 & Nick Eyre & U Oxford & 3 & 82 & 3 & 27.33 & 0 & 2 \\
\hline 24 & Massimo Filippini & ETH Zurich & 3 & 14 & 2 & 4.67 & 0 & 0 \\
\hline 25 & Brian P. O. Gallachoir & U College Cork & 3 & 21 & 3 & 7.00 & 0 & 0 \\
\hline 26 & Jeffery B. Greenblatt & U California Berkeley & 3 & 4 & 1 & 1.33 & 0 & 0 \\
\hline 27 & Eva Heiskanen & U Helsinki & 3 & 9 & 2 & 3.00 & 0 & 0 \\
\hline 28 & Marvin J. Horowitz & Demand Res LLC & 3 & 12 & 2 & 4.00 & 0 & 0 \\
\hline 29 & Maria T. Johansson & Linkoping U & 3 & 36 & 2 & 12.00 & 0 & 2 \\
\hline 30 & Steve Meyers & U California Berkeley & 3 & 19 & 3 & 6.33 & 0 & 0 \\
\hline 31 & Johannes Morfeldt & $\begin{array}{l}\text { KTH Royal Inst Technology } \\
\text { Zhaw Zurcher Hsch Angew }\end{array}$ & 3 & 21 & 2 & 7.00 & 0 & 1 \\
\hline 32 & Corinne Moser & Wissensch & 3 & 5 & 1 & 1.67 & 0 & 0 \\
\hline 33 & Vlasis Oikonomou & JIN Climate and Sustainability & 3 & 16 & 3 & 5.33 & 0 & 0 \\
\hline 34 & Dominique Osso & EDF-R\&D & 3 & 11 & 2 & 3.67 & 0 & 0 \\
\hline 35 & Christiane Pakula & U Hochschule Niederrhein & 3 & 63 & 3 & 21.00 & 1 & 1 \\
\hline 36 & Won Y. Park & U California Berkeley & 3 & 3 & 1 & 1.00 & 0 & 0 \\
\hline 37 & Ralph Prahl & Prahl \& Associates, & 3 & 25 & 3 & 8.33 & 0 & 1 \\
\hline 38 & Nihar Shah & Harvard U & 3 & 5 & 2 & 1.67 & 0 & 0 \\
\hline 39 & Patrik Thollander & Linkoping U & 3 & 128 & 2 & 42.67 & 1 & 1 \\
\hline 40 & Stefan Thomas & Wuppertal Inst Clima & 3 & 23 & 3 & 7.67 & 0 & 0 \\
\hline 41 & Juha Viholainen & Lappeenranta U Technology & 3 & 29 & 2 & 9.67 & 0 & 1 \\
\hline 42 & Tanja Winther & U Oslo & 3 & 22 & 2 & 7.33 & 0 & 1 \\
\hline
\end{tabular}

Abbreviations are available in previous tables except for: $\mathrm{H}=\mathrm{h}$-index; $\mathrm{C} / \mathrm{P}=\mathrm{Cites}$ per paper. 
Table 5. The most productive and influential institutions in Energy Efficiency

\begin{tabular}{cllcccccc}
\hline R & University & Country & TP & TC & TH & TC/TP & ARWU & QS \\
\hline 1 & U California Berkeley & USA & 43 & 543 & 12 & 12.63 & 5 & 28 \\
2 & Utrecht U & Netherlands & 15 & 230 & 6 & 15.33 & 47 & 104 \\
3 & Linkoping U & Sweden & 13 & 219 & 8 & 16.85 & $201-300$ & - \\
4 & Fraunhofer Gesellschaft & Germany & 11 & 77 & 5 & 7.00 & - & - \\
5 & Polytechnic U Milan & Italy & 9 & 52 & 5 & 5.78 & - & 183 \\
6 & Lund U & Sweden & 8 & 134 & 6 & 16.75 & $101-150$ & 73 \\
7 & U Bonn & Germany & 8 & 95 & 4 & 11.88 & $101-151$ & 231 \\
8 & U Oxford & UK & 8 & 115 & 5 & 14.38 & 7 & 6 \\
9 & De Montfort U & UK & 7 & 48 & 3 & 6.86 & - & - \\
10 & ETH Zurich & Switzerland & 7 & 53 & 4 & 7.57 & 19 & 8 \\
11 & KTH Royal Inst Technology & Sweden & 7 & 56 & 4 & 8.00 & $201-300$ & 97 \\
12 & U Coimbra & Portugal & 7 & 22 & 2 & 3.14 & $401-500$ & $451-460$ \\
13 & King Mongkut's U Techn Thonburi & Thailand & 6 & 74 & 4 & 12.33 & - & $701+$ \\
14 & Lappeenranta U Technology & Finland & 6 & 33 & 3 & 5.50 & - & $471-480$ \\
15 & U College Cork & Ireland & 6 & 36 & 4 & 6.00 & $601-700$ & 283 \\
16 & Chalmers U Technology & Sweden & 5 & 60 & 4 & 12.00 & $201-300$ & 139 \\
17 & Delft U Technology & Netherlands & 5 & 36 & 2 & 7.20 & $151-200$ & 62 \\
18 & Electricite de France EDF & France & 5 & 39 & 2 & 7.80 & - & - \\
19 & Georgia Inst Technology & USA & 5 & 38 & 3 & 7.60 & 85 & 71 \\
20 & Islamic Azad U & Iran & 5 & 9 & 2 & 1.80 & - & - \\
21 & U College London & UK & 5 & 20 & 3 & 4.00 & 16 & 7 \\
22 & U Geneva & Switzerland & 5 & 82 & 3 & 16.40 & 60 & 95 \\
23 & Aalborg U & Denmark & 4 & 72 & 3 & 18.00 & $201-300$ & 374 \\
24 & California Inst Energy Environ & USA & 4 & 20 & 3 & 5.00 & - & - \\
25 & CNRS France & France & 4 & 43 & 3 & 10.75 & - & - \\
\hline
\end{tabular}

Abbreviations are available in previous tables except for: ARWU = Academic Ranking of World Universities; QS = Quacquarelli \& Symonds University Ranking. 
Table 6. The most productive and influential countries in Energy Efficiency

\begin{tabular}{clcccccccc}
\hline $\mathrm{R}$ & Country & $\mathrm{TP}$ & $\mathrm{TC}$ & $\mathrm{TH}$ & $\mathrm{TC} / \mathrm{TP}$ & $>50$ & $>10$ & $\mathrm{TP} /$ Pop & TC/Pop \\
\hline 1 & USA & 116 & 978 & 16 & 8.43 & 1 & 3 & 0.36 & 3.04 \\
2 & UK & 49 & 525 & 12 & 10.71 & 0 & 2 & 0.74 & 7.88 \\
3 & Germany & 44 & 1009 & 14 & 22.93 & 2 & 3 & 0.54 & 12.39 \\
4 & Sweden & 42 & 518 & 13 & 12.33 & 1 & 1 & 4.29 & 52.86 \\
5 & Netherlands & 41 & 476 & 11 & 11.61 & 1 & 1 & 2.42 & 28.10 \\
6 & Italy & 27 & 181 & 8 & 6.70 & 0 & 0 & 0.44 & 2.98 \\
7 & Peoples R China & 27 & 167 & 7 & 6.19 & 0 & 0 & 0.02 & 0.12 \\
8 & Spain & 19 & 82 & 6 & 4.32 & 0 & 0 & 0.41 & 1.77 \\
9 & Finland & 18 & 106 & 6 & 5.89 & 0 & 0 & 3.28 & 19.34 \\
10 & France & 18 & 140 & 8 & 7.78 & 0 & 0 & 0.27 & 2.10 \\
11 & Switzerland & 17 & 184 & 7 & 10.82 & 0 & 0 & 2.03 & 21.98 \\
12 & Australia & 16 & 75 & 5 & 4.69 & 0 & 0 & 0.67 & 3.15 \\
13 & India & 16 & 191 & 5 & 11.94 & 1 & 1 & 0.01 & 0.15 \\
14 & Canada & 14 & 127 & 4 & 9.07 & 0 & 1 & 0.39 & 3.54 \\
15 & Portugal & 14 & 42 & 4 & 3.00 & 0 & 0 & 1.35 & 4.06 \\
16 & Norway & 13 & 117 & 6 & 9.00 & 0 & 0 & 2.50 & 22.52 \\
17 & Brazil & 12 & 107 & 5 & 8.92 & 0 & 0 & 0.06 & 0.52 \\
18 & Iran & 12 & 34 & 4 & 2.83 & 0 & 0 & 0.15 & 0.43 \\
19 & Ireland & 9 & 49 & 5 & 5.44 & 0 & 0 & 1.94 & 10.56 \\
20 & Austria & 8 & 36 & 4 & 4.50 & 0 & 0 & 0.91 & 4.12 \\
21 & South Korea & 8 & 9 & 2 & 1.13 & 0 & 0 & 0.16 & 0.18 \\
22 & Thailand & 8 & 83 & 5 & 10.38 & 0 & 0 & 0.12 & 1.21 \\
23 & Denmark & 7 & 78 & 4 & 11.14 & 0 & 0 & 1.23 & 13.74 \\
24 & Greece & 7 & 14 & 3 & 2.00 & 0 & 0 & 0.65 & 1.29 \\
25 & Japan & 7 & 88 & 4 & 12.57 & 0 & 0 & 0.06 & 0.69 \\
26 & Belgium & 5 & 41 & 3 & 8.20 & 0 & 0 & 0.44 & 3.63 \\
27 & Malaysia & 5 & 12 & 2 & 2.40 & 0 & 0 & 0.16 & 0.38 \\
28 & Taiwan & 5 & 11 & 3 & 2.20 & 0 & 0 & 0.21 & 0.47 \\
29 & Romania & 4 & 15 & 2 & 3.75 & 0 & 0 & 0.20 & 0.76 \\
30 & Turkey & 4 & 13 & 2 & 3.25 & 0 & 0 & 0.05 & 0.17 \\
\hline
\end{tabular}

Abbreviations are available in previous tables except for: TP/Pop = Total papers per million inhabitants; TC/Pop = Total citations million inhabitants. 
Table 7. Citing articles of Energy Efficiency: Authors, universities, countries and journals

\begin{tabular}{clclclc}
\hline R & University & TP & Country & TP & Author & TP \\
\hline 1 & U California Berkeley & 50 & USA & 388 & Thollander P & 22 \\
2 & Linkoping U & 45 & UK & 304 & Stamminger R & 21 \\
3 & Utrecht U & 44 & PR China & 265 & Worrell E & 20 \\
4 & Fraunhofer Gesellschaft & 41 & Germany & 198 & Cagno E & 14 \\
5 & Polytechnic U Milan & 33 & Sweden & 169 & Xia XH & 14 \\
6 & U Oxford & 32 & Netherlands & 144 & Lin BQ & 13 \\
7 & Delft U Technology & 28 & Italy & 137 & Trianni A & 13 \\
8 & Virginia Polytechnic Inst St U & 27 & Spain & 96 & Taylor JE & 12 \\
9 & Lund U & 26 & Australia & 95 & Wei YM & 11 \\
10 & U College London & 26 & Canada & 79 & Eichhammer W & 10 \\
11 & Chalmers U Technology & 25 & France & 71 & Patel MK & 10 \\
12 & Norwegian U Science Technology & 25 & Finland & 62 & Heiskanen E & 9 \\
13 & Beijing Institute of Technology & 24 & India & 56 & Levinson R & 9 \\
14 & Royal Institute of Technology & 24 & Japan & 56 & Oikonomou V & 9 \\
15 & Tsinghua U & 22 & Switzerland & 55 & Rosenow J & 9 \\
16 & Aalto U & 20 & Norway & 54 & Schleich J & 9 \\
17 & U Bonn & 20 & Denmark & 53 & Eyre N & 8 \\
18 & ETH Zurich & 19 & Austria & 44 & Galvin R & 8 \\
19 & U Leeds & 19 & Portugal & 40 & Gokdogan O & 8 \\
20 & U Coimbra & 18 & Iran & 39 & Kaushik SC & 8 \\
21 & U Cambridge & 18 & Brazil & 38 & Torriti J & 8 \\
22 & Columbia U & 16 & Turkey & 35 & Baran MF & 7 \\
23 & Helmholtz Association & 16 & Taiwan & 31 & Brown MA & 7 \\
24 & Stanford U & 16 & Greece & 30 & Delmas MA & 7 \\
25 & Xiamen U & 16 & Malaysia & 28 & Du HB & 7 \\
26 & Aalborg U & 15 & Belgium & 27 & Jain RK & 7 \\
27 & Loughborough U & 15 & South Korea & 27 & Liang QM & 7 \\
28 & National U Singapore & South Africa & 25 & Schlomann B & 7 \\
29 & Technical U Denmark & Poland & 22 & Schmitz A & 7 \\
30 & U Pretoria & & & & & 7 \\
\hline & & & & Palm J & \\
\end{tabular}

Abbreviations: $\mathrm{R}=$ Rank; $\mathrm{TP}=$ Total papers. 
Table 8. Co-citation of journals in Energy Efficiency: Global and temporal analysis

\begin{tabular}{|c|c|c|c|c|c|c|c|c|c|}
\hline & \multicolumn{3}{|c|}{ Global } & \multicolumn{3}{|c|}{$2008-2012$} & \multicolumn{3}{|c|}{ 2013-2017 } \\
\hline $\mathrm{R}$ & Journal & Cit & CLS & Journal & Cit & CLS & Journal & Cit & CLS \\
\hline 1 & Energ Policy & 1528 & 1028.35 & Energ Policy & 385 & 242.86 & Energ Policy & 1145 & 777.84 \\
\hline 2 & Energ Buildings & 568 & 403.84 & Energ Econ & 72 & 64.91 & Energ Buildings & 518 & 363.41 \\
\hline 3 & Energ Effic & 465 & 393.82 & Energy & 69 & 59.62 & Energ Effic & 405 & 341.85 \\
\hline 4 & Energy & 457 & 402.22 & Energ Effic & 64 & 52.23 & Energy & 388 & 340.97 \\
\hline 5 & Energ Econ & 326 & 281.24 & Energ Buildings & 50 & 39.63 & Energ Econ & 254 & 215.83 \\
\hline 6 & Appl Energ & 268 & 246.28 & Energy $\mathrm{J}$ & 37 & 32.42 & Appl Energ & 251 & 229.54 \\
\hline 7 & Build Environ & 229 & 179.85 & Energ Convers Manage & 29 & 24.01 & Build Environ & 211 & 164.1 \\
\hline 8 & Renew Sust Energ Rev & 181 & 170.95 & Ecol Econ & 23 & 22.61 & Renew Sust Energ Rev & 172 & 162.03 \\
\hline 9 & J Clean Prod & 152 & 135.32 & J Environ Psychol & 19 & 14.58 & J Clean Prod & 135 & 118.33 \\
\hline 10 & Energ Convers Manage & 151 & 136.08 & Build Environ & 18 & 15.76 & Energ Convers Manage & 122 & 111.19 \\
\hline 11 & Ecol Econ & 125 & 119.86 & J Environ Econ Manag & 18 & 15.77 & Ecol Econ & 102 & 97.17 \\
\hline 12 & Energy $\mathrm{J}$ & 114 & 100.97 & Appl Energ & 17 & 16.47 & Renew Energ & 87 & 78.74 \\
\hline 13 & Renew Energ & 101 & 91.96 & J Clean Prod & 17 & 16.73 & Energy J & 78 & 70.08 \\
\hline 14 & J Environ Psychol & 92 & 80.94 & Energy Env & 15 & 14.92 & Appl Therm Eng & 77 & 68.4 \\
\hline 15 & Appl Therm Eng & 88 & 77.01 & Renew Energ & 14 & 12.89 & J Environ Psychol & 73 & 64.34 \\
\hline 16 & Build Res Inf & 74 & 68.57 & Resour Energy Econ & 14 & 13.87 & Build Res Inf & 64 & 59.43 \\
\hline 17 & Sol Energy & 59 & 52.11 & Science & 14 & 13.35 & Sol Energy & 53 & 46.28 \\
\hline 18 & Resour Energy Econ & 53 & 52.05 & Ashrae J & 12 & 11.14 & Am Econ Rev & 43 & 41.31 \\
\hline 19 & Am Econ Rev & 50 & 48.29 & Ashrae Tran & 12 & 10.42 & Int J Refrig & 42 & 28.21 \\
\hline 20 & Environ Behav & 49 & 45.38 & Environ Behav & 12 & 10.75 & Resour Energy Econ & 39 & 38.17 \\
\hline 21 & Rev Econ Stat & 48 & 45.48 & Appl Therm Eng & 11 & 8.56 & Rev Econ Stat & 39 & 36.64 \\
\hline 22 & Int J Refrig & 47 & 32.9 & Environ Resour Econ & 11 & 10.77 & Environ Behav & 37 & 34.16 \\
\hline 23 & Eur J Oper Res & 41 & 35.2 & World En Outl & 11 & 6 & Econometrica & 32 & 30.29 \\
\hline 24 & J Environ Econ Manag & 39 & 36.44 & Build Res Inf & 10 & 9.04 & Eur J Oper Res & 32 & 27.08 \\
\hline 25 & Ashrae T & 36 & 30.28 & Communication & 10 & 3.8 & IEEE T Smart Grid & 31 & 23.1 \\
\hline 26 & Econometrica & 36 & 34.32 & Clim Policy & 9 & 6.76 & $\mathrm{~J}$ Econometrics & 31 & 29.46 \\
\hline 27 & $\mathrm{~J}$ Econometrics & 36 & 34.03 & Eur J Oper Res & 9 & 8.03 & Energy Sustain Dev & 30 & 28.65 \\
\hline 28 & Resour Conserv Recy & 32 & 30.84 & J Consum Res & 9 & 7.87 & Int J Consum Stud & 28 & 22.62 \\
\hline 29 & Energy Sustain Dev & 32 & 30.65 & Renew Sust Energ Rev & 9 & 8.83 & IEEE T Ind Electron & 28 & 21.83 \\
\hline 30 & Science & 32 & 30.3 & Rev Econ Stat & 9 & 8.74 & Resour Conserv Recy & 27 & 26.02 \\
\hline
\end{tabular}

Abbreviations: Cit $=$ Citations; CLS $=$ Citation link strength. 
Table 9. Co-occurrence of author keywords in Energy Efficiency: Global and temporal analysis

\begin{tabular}{|c|c|c|c|c|c|c|c|c|c|}
\hline & \multicolumn{3}{|l|}{ Global } & \multicolumn{3}{|l|}{$2008-2012$} & \multicolumn{3}{|l|}{$2013-2017$} \\
\hline $\mathrm{R}$ & Keyword & Occ & Co-oc & Keyword & Occ & Co-oc & Keyword & Occ & $\mathrm{Co}-\mathrm{Oc}$ \\
\hline 1 & Energy Efficiency & 175 & 127 & Energy Efficiency & 68 & 54 & Energy Efficiency & 107 & 90 \\
\hline 2 & Energy Savings & 27 & 20 & Energy Savings & 9 & 8 & Energy Savings & 18 & 16 \\
\hline 3 & Energy Consumption & 18 & 13 & Buildings & 6 & 6 & Energy Consumption & 13 & 11 \\
\hline 4 & Demand Response & 14 & 12 & Evaluation & 6 & 5 & Demand Response & 11 & 9 \\
\hline 5 & Energy Policy & 13 & 12 & Energy Consumption & 5 & 3 & Smart Grid & 10 & 9 \\
\hline 6 & Buildings & 11 & 8 & Energy Intensity & 5 & 1 & Energy Policy & 8 & 7 \\
\hline 7 & Energy Conservation & 11 & 8 & Energy Policy & 5 & 5 & Energy & 7 & 6 \\
\hline 8 & Energy Intensity & 11 & 6 & Rebound Effect & 5 & 4 & Energy Conservation & 7 & 6 \\
\hline 9 & Rebound Effect & 11 & 7 & Renewable Energy & 5 & 5 & Residential & 7 & 7 \\
\hline 10 & Barriers & 10 & 10 & White Certificates & 5 & 4 & Barriers & 6 & 6 \\
\hline 11 & Evaluation & 10 & 9 & Barriers & 4 & 4 & Decomposition Analysis & 6 & 5 \\
\hline 12 & Renewable Energy & 10 & 8 & Climate Policy & 4 & 4 & Energy Efficiency Policy & 6 & 4 \\
\hline 13 & Residential & 10 & 9 & Efficiency & 4 & 4 & Energy Intensity & 6 & 5 \\
\hline 14 & Smart Grid & 10 & 7 & Energy Conservation & 4 & 3 & Industrial Energy Efficiency & 6 & 5 \\
\hline 15 & Energy & 9 & 6 & Energy Services & 4 & 3 & Rebound Effect & 6 & 4 \\
\hline 16 & Energy Efficiency Policy & 9 & 5 & Market Transformation & 4 & 3 & Appliances & 5 & 4 \\
\hline 17 & Market Transformation & 9 & 6 & Policy & 4 & 4 & Buildings & 5 & 4 \\
\hline 18 & Energy Services & 8 & 7 & Sweden & 4 & 3 & $\mathrm{CO} 2$ Emissions & 5 & 5 \\
\hline 19 & Policy & 8 & 6 & Behaviour & 3 & 2 & Electricity & 5 & 5 \\
\hline 20 & Sweden & 8 & 8 & Climate Change & 3 & 3 & Energy Management & 5 & 4 \\
\hline 21 & Appliances & 7 & 6 & Data Envelopment Analysis & 3 & 2 & Household Technology & 5 & 4 \\
\hline 22 & Climate Change & 7 & 6 & Decision-Making & 3 & 2 & Market Transformation & 5 & 5 \\
\hline 23 & Data Envelopment Analysis & 7 & 5 & Demand Response & 3 & 3 & Renewable Energy & 5 & 4 \\
\hline 24 & Decomposition Analysis & 7 & 6 & Demand-Side Management & 3 & 3 & Behaviour Change & 4 & 4 \\
\hline 25 & Electricity & 7 & 5 & Electricity Consumption & 3 & 3 & Benchmarking & 4 & 2 \\
\hline 26 & Building & 6 & 5 & Energy Efficiency Policy & 3 & 3 & Building & 4 & 4 \\
\hline 27 & CO2 Emissions & 6 & 5 & Greenhouse Gas Mitigation & 3 & 3 & Climate Change & 4 & 3 \\
\hline 28 & Cost-Effectiveness & 6 & 5 & Household & 3 & 3 & Commercial Buildings & 4 & 3 \\
\hline 29 & Efficiency & 6 & 4 & Industry & 3 & 3 & Cost-Effectiveness & 4 & 3 \\
\hline 30 & Electricity Consumption & 6 & 6 & Labeling & 3 & 3 & Data Envelopment Analysis & 4 & 4 \\
\hline
\end{tabular}

Abbreviations: Occ $=$ Occurrences; Co-oc $=$ Co-occurrence link strength 